Journal of the Scientific Agricultural Society of Finland

Vol. 46: $347-3941974$

Maataloustieteellinen Aikakauskirja

\title{
MAATALOUDEN RAKENNERATIONALISOINNIN LIIKETALOUDELLISISTA EDELLYTYKSISTÄ
}

Abstract: On micro-economic preconditions required for the structural change in agriculture. Studies of farm growth in South Finland.

K A R L J O H A N W E C K M A N

Helsingin Yliopisto, Maanviljelystalouden laitos, Viikki

University of Helsinki, Department of Agricultural

Economics, SF-00710 Helsinki 71

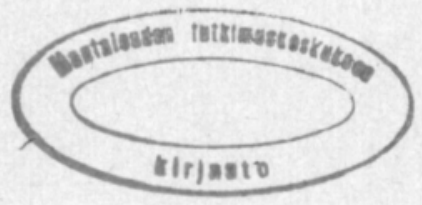





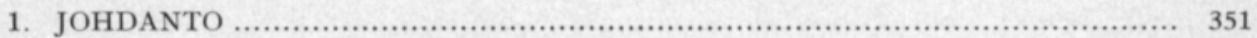

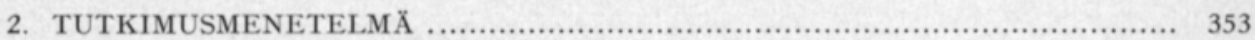

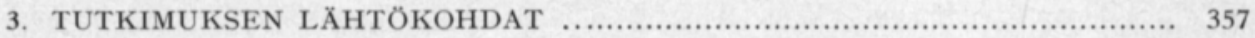

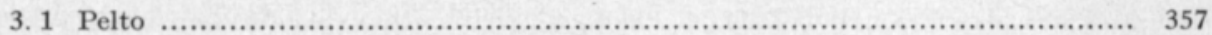

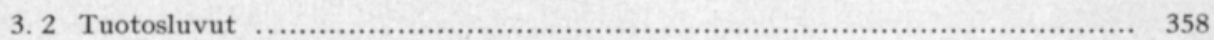

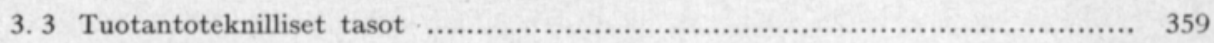

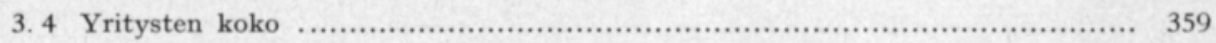

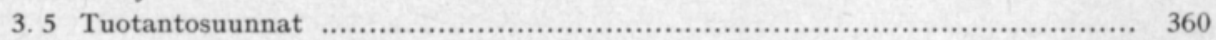

4. NUMEROAINEISTON SOVITTAMINEN MC-MENETELMÄÄ VARTEN .......... 361

4. 1 Rakennuskustannukset ....................................................................... 362

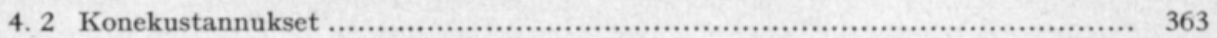

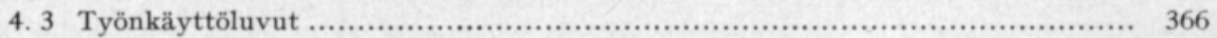

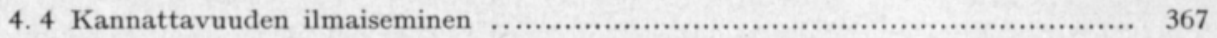

4. 5 Mallien konstruoiminen ja ratkaisumenettely …................................... 367

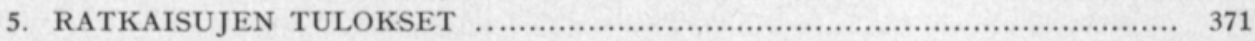

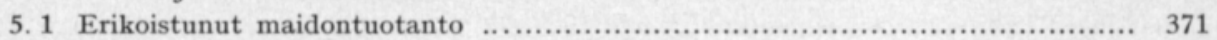

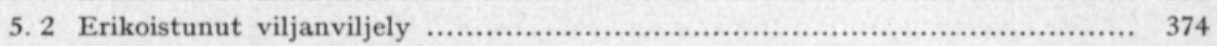

6. MAATALOUSYRITYSTEN KASVUONGELMAT …................................... 378

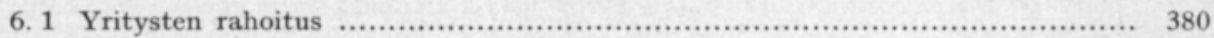

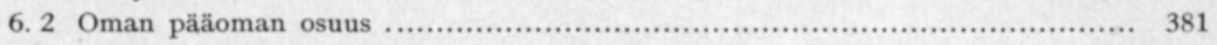

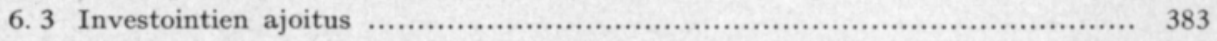

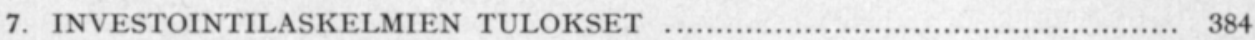

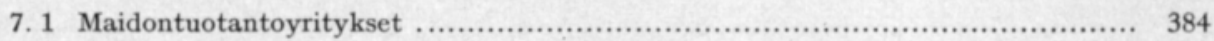

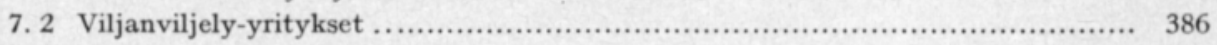

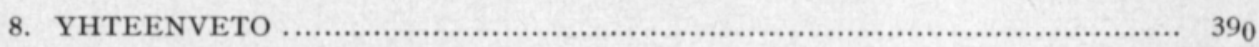

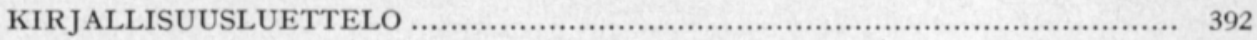

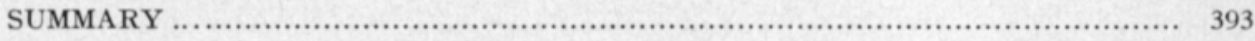


Weckman, K. J. 1974. On micro-economic preconditions required for the structural change in agriculture. Studies of farm growth in South Finland. J. Scient. Agric. Soc. Finl. 46: 347-394.

Abstract. The purpose of the investigation was to study the micro-economic aspects of structural changes in finnish agriculture. To find the solution for an individual farm model, the Monte Carlo-method was used. The investigation used the method of comparative statics, as the situation of the farms was examined after they had reached a specified size.

As the transition from one size to another takes time, calculations were made to estimate the paying readynes of the farms during the period of transition.

The investigation shows that considerable economic gain could be made on the average farm both when moving to a larger enterprise and on the same time moving to a more advanced level of production techniques.

The calculations concerning the paying readynes revealed on the other hand that the difficulties encountered during the transitional period could easily endanger the paying readynes of the enterprise. The difficulties in making payments reached a critical stage when the proportion of loaned capital grew to about one half of the entire capital on the average farm.

The investigation confirmed a pressing need for capital on all alternative types of farms, and this need grew with the increase in size and technical level. On the basis of these results fast structural changes in Finnish agriculture seem unlike to happen in the near future. 


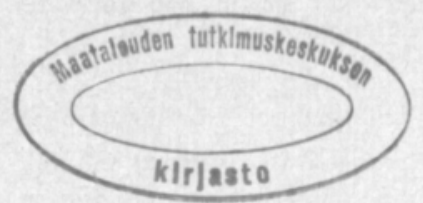

\section{Johdanto}

Rakennerationalisointiin on viime aikoina kiinnitetty yhä enemmän huomiota maatalouselinkeinon taloudellisista edellytyksistä keskusteltaessa. Yritysten rakennemuutoksilla tarkoitetaan tässä tutkimuksessa muutoksia yrityskokoelman yksityisten yritysten koossa. Suomen maatilataloudessa on yrityskokoa perinteellisesti mitattu pelto- tai kokonaispinta-alan avulla. ABEL (1958) osoittaa, että maatalousyritysten kokoa mitattaessa yleensä käytetään mittapuuna sitä tuotannontekijää, josta on suurin puute. Tässä mielessä tuotannonalan laajuus on Suomessa epäilemättä ollut sopiva osoittamaan maatalousyrityksen kokoa. Mm. maatalouden erikoistuminen on kuitenkin johtanut siihen, että mainittu mittaustapa ajan mukaan on muuttumassa epätarkemmaksi. Varsinkin yritysten kasvuongelmaa käsiteltäessä tämä mittaustapa tuntuu liian yksipuoliselta. Tutkimuksessa käsiteltyjen yritysmallien vertailussa koon suhteen olisi tämän takia kirjoittajan mielestä parasta käyttää mittapuuna yritysten eri pääomien määrää pinta-alan rinnalla. Vaikein tehtävä tässä yhteydessä tulee epäilemättä olemaan peltopääoman osuuden arvioimiminen (MoHR 1971).

Rationalisoinnin yleisiä edellytyksiä on alueittain tutkittu mm. seutukaavoituksen yhteydessä. Maatalouskeskukset suorittavat parhaillaan peltoalan luokituksia alueillaan (WECKMAN 1972). Työ suoritetaan maatilahallituksen toimeksiannosta. Mainitut tutkimukset selvittävät lähinnä tilakohtaisten peltoalan laajennusten edellytykset (TUisku 1973). Alan kehitystä on myöskin ennustettu eri kyselyjen tulosten perusteella. TORVELA (1972) on kirjanpidon pohjalta tutkinut erisuuruisten yritysten ja eri tuotantosuuntien kannattavuutta.

TORVELA ja MäKI (1974) ovat tutkineet perheviljelmän suuruuskysymyksiä käytettäessä eritasoista tekniikkaa tuotantoprosesseissa. Tutkimuksessa on pyritty muodostettujen viljelmämallien avulla määrittämään, minkä kokoista viljelmäă 2,5 henkeä käsittävä perhe voi normaaleissa olosuhteissa eri tuotantomuotoja harjoittaen hoitaa. Perheviljelmä on rajoitettu määrittämään tavallaan teknisesti kiinnittämällä huomiota $\mathrm{mm}$. viljelmän pääomatarpeeseen, viljelmältä saatuun taloudelliseen tulokseen ja viljelijäperheen toimeentuloon. Tutkimuksessa on keskitytty tarkastelemaan sinänsä erittäin vaikeata kysymystä, kuinka suurta maatilaa viljelijäperhe eri tapauksissa voi hoitaa.

Tutkimuksen tuloksista ilmenee, että puhtaasti tekniseltä kannalta viljelijäperhe voisi hoitaa suhteellisen suuria yrityksiä verrattuna maatilojen nykyiseen keskikokoon. Tutkimuksessa ei kuitenkaan ole voitu selvittää mahdollisuuksia tällaisten yritysten syntymiseen. 
Ruotsissa ovat BringBorn ja Hovmark (1971) tutkineet teknisen ja taloudellisen kehityksen vaikutusta maatalousyrityksiin. Tutkimuksessa on vertailtu erilaisten tuotantosuuntien ja teknisten tasojen kannattavuutta MälarHjälmarin seudulla.

Yrityksen rakenteeseen vaikuttavat toimenpiteet vaativat meillä useimmissa tapauksissa suhteellisen suuria investointeja. Näiden investointien oletetusta kannattavuudesta ja niiden vaikutuksesta koko yrityksen kannattavuuteen riippuu hyvin paljon, missä määrin investointipäätöksiä tulevaisuudessa tullaan tekemään. Valtiovallalla on tiettyjä mahdollisuuksia vaikuttaa mainittujen investointien kannattavuuteen, mutta se voi päätöksillään myös jarruttaa kehitystä. Liiketaloudellisten päätösten ohella olisi siis myös kansantalouden kannalta tärkeää tietää, kuinka suuria tilakohtaisia investointeja keskimäärin tarvitaan ja kuinka kannattavia ne ovat.

Tutkimukseni tarkoituksena on yllä mainittujen ongelmien valottaminen lähinnä Uudenmaan ruotsinkielisen maanviljelysseuran alueella. Tilamallien avulla pyrin arvioimaan eri tuotantosuuntien, tuotantotasojen ja erisuuruisten yritysten kannattavuutta. Tällä tavalla yritän selvittää, millaisilla yrityksillä on parhaat liiketaloudelliset menestymismahdollisuudet. Näille yrityksille esitän tämänjälkeen investointi- ja maksuvalmiuslaskelmia. Yhtenä lähtökohtana pidän sitä yritysrakenteen tilannetta tutkimusalueella, joka todettiin aikaisempien ns. kuntatutkimusten yhteydessä (WЕСКмAN 1972).

Erityistä huomiota tulen kiinnittämään pääomakysymyksiin: määrititetään koko pääoman suuruus sekä sen jakaantuminen oman ja vieraan pääoman kesken. Jo etukäteen voidaan olettaa, että korkeaa tuotantotekniikkaa käyttävien yritysten pääomantarve tulee olemaan suuri. 


\section{Tutkimusmenetelmä}

Tutkimusaihe on luonteeltaan selvästi dynaaminen. Tarkoitukseen käyttökelpoisia dynaamisia malleja ei kuitenkaan ole helppo konstruoida. Ruotsissa on OLsson (1970) kehitellyt monijaksoisen, lineaariseen ohjelmointiin perustuvan mallin tätä tarkoitusta varten. Tekniikka on hyvin tunnettu ja mm. Swansson (1955), Loftsgard ja Heady (1959) sekä Boehlje ja White (1969) ovat aikaisemmin käyttäneet sitä tähän tarkoitukseen. Olssonin yritys on kunnianhimoinen ja pyrkii ottamaan huomioon useimmat kasvuongelmaan vaikuttavat tekijät.

OLsson käyttää kolmea viiden vuoden jaksoa ja suunnitteluhorisontti on näin ollen sijoitettu 15 vuoden päähän. Voidaankin kysyä, millä tavalla on mahdollista estimoida lukuja, jotka esimerkiksi ilmaisevat yleistä teknistä kehitystä tänä aikana. Menetelmä muistuttaa dynaamisesta luonteestaan huolimatta vertailevia staattisia menetelmiä, koska yritys kasvaa vain siirryttäessä jaksolta toiselle. Diskonttausmenettely, jota tarvitaan tällaisten mallien yhteydessä, lienee varsin monimutkainen ja työtä vaativa.

Tässä työssä pyrin lähinnä tutkimaan sellaisia rationalisointitoimenpiteitä, jotka teknisesti voitaisiin suorittaa viivytyksittä, mikäli olosuhteet muuten sen sallivat. Tästä syystä olen valinnut vertailevan staattisen etenemistavan tutkimusta varten.

Laskumenetelmän valinnassa on tarjolla useita vaihtoehtoja. Laskelmat voidaan tehdä käsin normaalia budjetti- tai katetuottomenetelmää käyttäen. Tätä tarkoitusta varten voidaan myöskin soveltaa lineaarista ohjelmointia. Olen kuitenkin - osittain kokeilunkin vuoksi - valinnut Ruotsissa kehitetyn ns. Monte Carlo (MC) -laskumenetelmän, koska voidaan olettaa, että MC-menetelmä tarjoaa tietynlaisia etuja eräisiin muihin menetelmiin verrattuna. Ennen kaikkea se seikka tuntuu mielekkäältä, ettei malleissa tarvitse etukäteen määrittää kiinteää panos-tuotossuhdetta eri tuotannonhaaroille. Myös useiden samanarvoisten vaihtoehtoisten tulosten saaminen voi jossakin määrin olla eduksi päätöksenteossa. Maksimi- ja minimirajoitusten avulla voidaan myös helposti etukäteen määrätä kaikkien variaabelien vaihteluväli.

Monte Carlo-menetelmää voidaan yksinkertaisimmin luonnehtia'siten, että suunnitteluongelman jokaiselle muuttujalle annetaan satunnaiset arvot etukäteen määrätyin rajoituksin, jonka jälkeen kohdefunktio ratkaistaan. Tällöin on saatu yksi tulos. Toimitus toistetaan sen jälkeen hyvin monta kertaa. Muuttujien arvot tilanteessa, jossa paras tulos on saavutettu, muodostavat suunnitteluongelman ratkaisun. Mikäli muuttujien lukumäärä on suuri, voidaan olettaa, että löytyy paljon kombinaatioita, jotka ovat lähellä maksimi- 
tulosta. Yksi tai useampi tällainen tulos voidaan todennäköisesti edellä kuvatulla tavalla melko helposti löytää. Mikäli melkein samanarvoisten huipputulosten variaabelien arvoissa esiintyy ratkaisevia eroja, voi päätöksentekijä valita sen ratkaisun, joka eniten myötäilee hänen pyrkimyksiään. Monte Carlo -menetelmä mahdollistaa tällöin sellaisten tekijöiden huomioonottamisen, joita ei ole voitu kvantitatiivisesti sisällyttää varsinaiseen malliin.

Menetelmä on erityisen sopiva niissä tilanteissa, joissa ei pyritä absoluuttiseen maksimiin, vaan tyydytään tietyn tason ylittävään tulokseen. Matemaattisesti menetelmää voidaan CARLssonin, Hovmarkin ja Lindgrenin (1969, p. 81) mukaan kuvata seuraavasti:

On annettu yksi tai useampi kohdefunktio

$$
Z\left(x_{1}, x_{2}, \ldots, x_{j}, \ldots x_{n}\right) \text {, }
$$

missä $x_{j}$ on $j$ :nnen muuttujan arvo.

1) Muuttujat saavat arvoja alueelta $x_{j \min } \leq x_{j} \leq x_{j \text { maks }}$ mutta voivat myöskin saada arvon nolla. 2) Sallitaan sekä kokonaisia että kymmenyslukuja. Muuttujista, joiden lukumäärä on $\mathrm{n}$, voi k kappaletta olla riippumattomia; $\mathrm{n}-\mathrm{k} \mathrm{kpl}$ on siinä tapauksessa riippuvia. Riippumaton muuttuja voi saada arvoja täysin riippumatta siitä, mitkä arvot toiset riippumattomat muuttujat ovat saaneet. Riippuvien muuttujien arvot määräytyvät riippumattomien muuttujien arvojen perusteella seuraavasti:

$$
\begin{aligned}
& \mathrm{x}=\sum_{\mathrm{k}}^{\mathrm{k}}+\mathrm{h} \\
& \mathrm{j}=1
\end{aligned} \mathrm{D}_{\mathrm{h}, \mathrm{j}} \mathrm{x}_{\mathrm{j}} \quad(\mathrm{h}=1,2, \ldots, \mathrm{n}-\mathrm{k})
$$

$\mathrm{D}_{\mathrm{h}, \mathrm{j}}$ voi saada minkälaisia arvoja tahansa ja se voi myöskin olla yhden tai useamman muuttujan funktio.

Rajoitusten yleinen muoto on:

$$
\begin{aligned}
& \sum_{j=1}^{k} R_{i j} \leq b_{j}, \text { missä } \begin{array}{ll}
R_{i j}=q_{i j}+a_{i j} x_{j} & \text { jos } x_{j} \neq 0 \\
R_{i j}=0 & \text { jos } x_{j}=0
\end{array} \\
& (\mathrm{i}=1, \ldots, \mathrm{m})
\end{aligned}
$$

$a_{i j} j a b_{i}$ ovat ei-negatiivisia vakioita

$\mathrm{q}_{\mathrm{ij}}+\mathrm{a}_{\mathrm{ij}} \mathrm{x}_{\mathrm{j}} \min \geq 0$ mutta $\mathrm{q}_{\mathrm{ij}}$ on muten täysin vapaa.

Eri kombinaatioıden etsintä tapahtuu vaiheittain seuraavasti:

1) Valitaan satunnaisesti yksi riippumaton muuttuja ja annetaan tälle satunnainen arvo. Tarkastetaan, että kaikki rajoitukset on otettu huomioon. Ellei näin ole, muuttujan arvoa pienennetään, kunnes ehto on täytetty. Mikäli muuttuja tällöin saa arvon, joka on pienempi kuin $x_{\mathrm{j}}$ min, muuttujan arvo lasketaan nollaan. Vaihe toistetaan, kunnes etukäteen määrätty määrä muuttujista on saanut nollasta poikkeavan arvon tai kunnes kaikki riippumattomat muuttujat on käyty kerran läpi.

2) Täydennysvaiheen aikana käydään muuttujat läpi uudestaan samassa järjestyksessä kuin aikaisemmin. Muuttujien arvoja suurennetaan tällöin niin paljon kuin rajoitukset sallivat. 
3) Riippuvien muuttujien arvot lasketaan.

4) Kohdefunktioiden arvot lasketaan.

Menetelmän heikkoudet ovat luonteeltaan etupäässä teoreettisia. Ei ole tyydyttävästi ratkaistu, montako tulosta on laskettu, jotta paras tai parhaat tulokset sijaitsisivat tarpeeksi lähellä optimitulosta. Tätä etäisyyttä ei voida riittävän tarkasti mitata.

CARLSSON (1970) on kuitenkin osoittanut, että paras MC-tulos verraten pienestä tulosjoukosta sijaitsee suhteellisen lähellä sellaista saman suunnitteluongelman optimitulosta, joka on saatu esimerkiksi lineaarisella ohjelmoinnilla. Käytännössä tämä heikkous ei ehkä kuitenkaan ole ratkaiseva. Esimerkiksi maatilan taloussuunnitelman laadinnan yhteyeessä voidaan todeta, mitä olisi tehtävä, jotta tietty tulotaso olisi mahdollista saavuttaa. Tämä on ehkä monessa suhteessa riittävä tietomäärä päätöksentekoa varten, varsinkin kun MC-menetelmä antaa useissa tapauksissa monta vaihtoehtoista toimintaohjelmaa. Varsinaiseen tietojenkäsittelyohjelmaan on myöskin otettu mukaan tekijöitä, joiden vaikutusta tulosten hajontaan ei ole täydellisesti selvitetty.

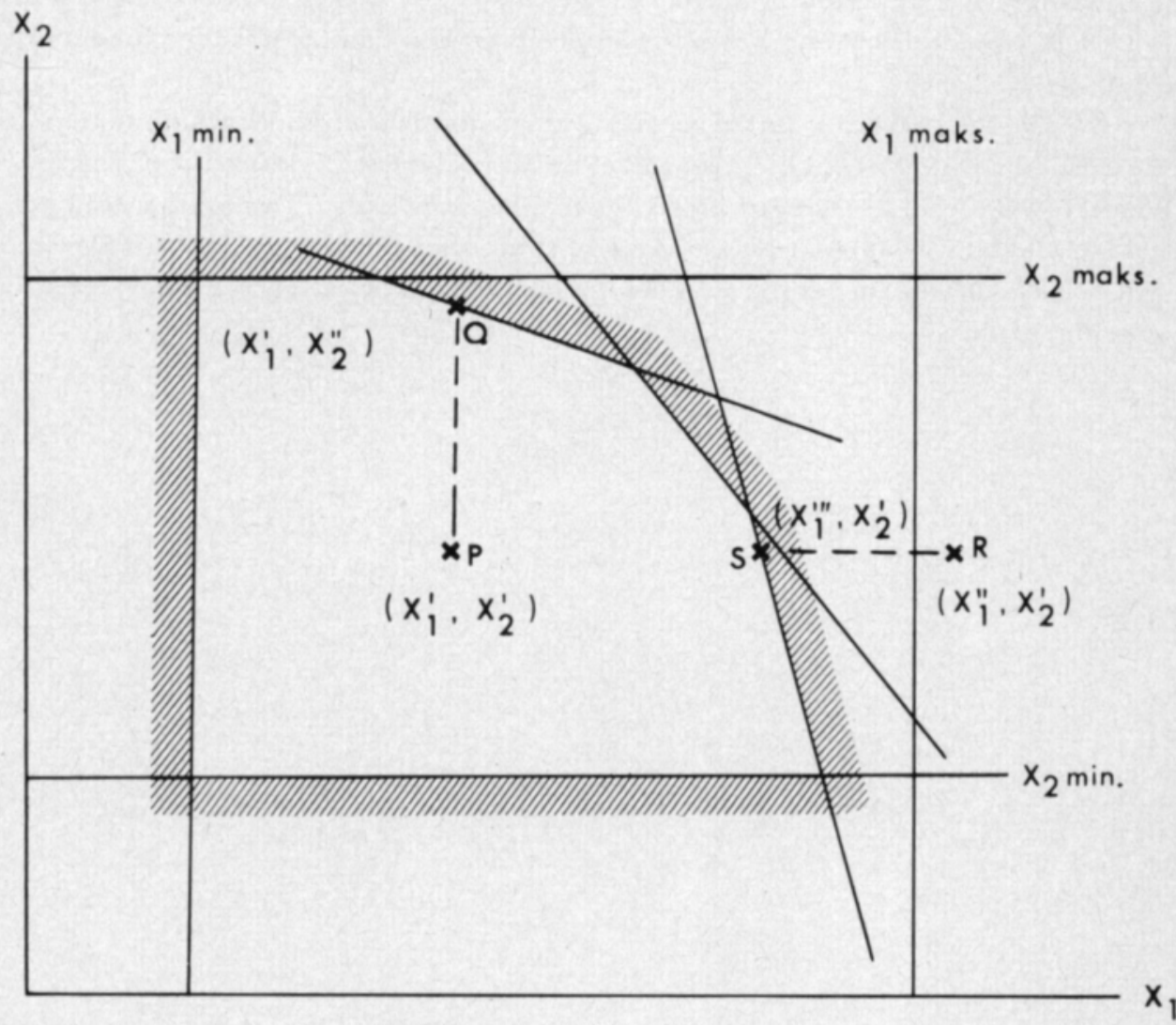

Kuvio 1.

Fig. 1. 
Edellä esitetyt huomautukset koskevat lähinnä MC-suunnittelumenetelmän teoreettista taustaa. Käytännön suunnittelussa mainitut teoreettiset heikkoudet on otettava huomioon lähinnä epävarmuustekijöinä.

Monte Carlo-menetelmää voidaan havainnollistaa graafisesti (ks. kuvio 1) Tehtävänä on tässä määrätä tuotantolaajuus kahdelle tuotteelle $x_{1}$ ja $x_{2}$. Tuotantoa voidaan harjoittaa tiettyjen rajoitusten sallimalla alueella. Pääasiallisimpina rajoituksina esiintyvät maksimi- ja minimiehdot molemmille tuotteille. Muut rajoitukset ovat tässä tapauksessa myös saaneet suoraviivaisen muodon. Näitä rajoituksia ovat esimerkiksi maataloudessa käytettävissä oleva työvoima ja peltoala.

Kahdesta tuotteesta valitaan esim. $x_{2}$ ja annetaan tälle sattumanvaraisesti laajuus $x_{2}$ ja sen jälkeen $x_{1}$ :lle laajuus $x_{1}^{*}$. Piste $P$ osoittaa tällöin äsken kuvatun tilanteen. Huomataan, että piste osoittaa täysin mahdollisen tuoteyhdistelmän. Sekä pää- että sivuehdot on täytetty. Edellä kohdassa 2 kuvatun täydennysmenettelyn yhteydessä $\mathrm{x}_{2}$ saa maksimiarvonsa $\mathrm{x}_{2}^{\prime \prime}$ kun $\mathrm{x}_{1}$ :n arvo pysyy ennallaan. Piste $Q$ osoittaa nyt yhden käyvän ratkaisun. Mikäli ensimmäisen toimituksen yteydessä $\mathrm{x}_{1}$ olisi satunaisesti saanut arvon $x_{1}^{*}$, olisi rajoitukset ylitetty. Pisteessä $R$ on $x_{2}$ saanut arvon $x_{2}^{\prime}$. Tässä tilanteessa $x_{1}$ :n arvoa on pienennettävä niin paljon, että rajoitusehdot on täytetty. Tämä tapahtuu pisteessä $S$, missä $x_{1}$ saa arvon $x_{1}^{*}$. Piste $S$ muodostaa tällöin toisen käyvän ratkaisun. Eri ratkaisuille lasketaan tämän jälkeen kohdefunktion arvot.

Kaikki ne ratkaisut, jotka eivät täytä rajoitusvaatimuksia suljetaan pois kuvatulla tavalla. Kaikki ratkaisut tulevat kohdassa 2 kuvatun täydennysmenettelyn ansiosta sijaitsemaan käyvän alueen rajoilla. Tämä aiheuttaa sen, että minkään variaabelin arvoa ei voida suurentaa pienentämättä samalla jonkin toisen variaabelin arvoa. Menetelmää voidaan tässä vertailla lineaariseen ohjelmointiin. 


\section{Tutkimuksen lähtökohdat}

\subsection{Pelto}

Laskelmia ei ole sidottu määrättyihin, jo olemassa oleviin yrityksiin. Päämääränä on verrata eri tuotantosuuntia ja erisuuruisia yrityksiä keskenään. Tämä saavutetaan yhdistämällä peltoa ja pääomaa tiettyihin etukäteen valittuihin vaihtoehtoisiin työpanoksiin niin edullisesti kuin mahdollista. Tarvittava lukuaineisto on kerätty Uudenmaan ruotsinkielisen maatalousseuran alueeelta. Tämän takia ne luontaiset edellytykset, joissa yritykset toimivat vastaavat lähinnä Uudenmaan olosuhteita. Laskelmissa tämä on otettu huomioon lähinnä käyttämällä kyseisen alueen tuotoslukuja ja hinnoittelemalla pelto alueen arvioidun hintatason mukaisesti (syksy 1973).

Aikaisemman tutkimukseni (WECKMAN 1972) yhteydessä Liljendalin ja Snappertunan kuntien pellot on jaettu kolmeen luokkaan:

Pysyvä pelto. Tähän luokkaan kuuluvat sellaiset peltoalueet, joiden viljely on liiketaloudellisesti kannattavaa myös pitkähkönä ajanjaksona.

Marginaalipelto. Tällaista peltoa viljellään ehkä vielä kauan, mutta tutkimuksessa on oletettu, että viljeleminen vaikeutuu ja tulee pitkähkön ajanjakson jälkeen liiketaloudellisesti kannattamattomaksi.

Poistuva pelto. Pelto joudutaan melko pian poistamaan viljelyksestä, koska se ei täytä pysyvän eikä marginaalipellon vaatimuksia.

Tämä tutkimus käsittelee vain sellaisia tiloja, joiden pellot kuuluvat luokkaan pysyvä pelto. Siksi pyrin selvittämään, mistä lähtökohdasta rakennerationalisointi yleensä olisi aloitettava tämän peltoluokan tiloilla.

Lisäpeltoa on tilamalleissa oletettu olevan vapaasti tarjolla. Keskihinnaksi on arvioitu $5000 \mathrm{mk}$ hehtaarilta. Aikaisempien tutkimusten mukaan on tutkimusalueella salaojitettu n. $60 \%$ pysyvästä pellosta. Salaojitus maksaa Salaojitusyhdistyksen ilmoituksen mukaan n. $1600 \mathrm{mk}$ hehtaarilta (syksy 1973). Laskelmissa oletetaan, että pellon keskihintaan sisältyy noin puolet salaojituskustannuksista.

Pellon vuokra on tutkimuksessa $300 \mathrm{mk}$ hehtaarilta. Tätä vuokraa on käytetty kaikissa kannattavuuslaskelmissa. Pääomatarvetta ja -hankintaa koskevissa laskelmissa on kuitenkin lähdetty siitä, että yritykset joutuvat ostamaan lisäpeltonsa. 


\subsection{Tuotosluvut}

Rakennerationalisoinnin yleisiä edellytyksiä koskevan tutkimukseni yhteydessä (WECKMAN 1972) selvitettiin myös keskimääräinen tuotostaso tutkimusalueella. Näitä keskimääräisiä tuotoslukuja on käytetty myös tässä tutkimuksessa. Tuotokset on kuitenkin sovitettu laskelmissa käytettyihin rehuja väkilannoitepanoksiin. Kotieläinvaihtoehdossa saatavan lannan levityskustannukset on arvioitu suurin piirtein yhtä suuriksi kuin vastaavan väkilannoitemäärän hinta ynnä levityskustannukset. Panos-tuotos-tason yhteensovittaminen on tapahtunut käytettävissä olevien normilukujen, perusteella. Seuraavassa esitetään laskelmissa käytetyt siementen, lannoitteiden ja satojen panos-tuotos -luvut.

Taulukko 1. Laskelmissa käytetyt siemen-, lannoite- ja satomäärät.

Table 1. Estimated input-output data used.

\begin{tabular}{|c|c|c|c|c|c|c|c|}
\hline \multirow{2}{*}{$\begin{array}{l}\text { Kasvi } \\
\text { Crop }\end{array}$} & \multirow{2}{*}{$\begin{array}{c}\text { Siemen } \\
\text { Seed } \\
\mathrm{kg} / \mathrm{ha}\end{array}$} & \multirow{2}{*}{$\begin{array}{c}\text { Sato } \\
\text { Yield } \\
\mathrm{kg} / \mathrm{ha}\end{array}$} & \multicolumn{5}{|c|}{ Lannoitus Fertilizer $\mathrm{kg} / \mathrm{ha}$} \\
\hline & & & $\begin{array}{l}\text { Fosforir. } \\
\text { super-Y }\end{array}$ & $\begin{array}{l}\text { Oulun } \\
\text { salp. }\end{array}$ & $\begin{array}{l}\text { Boorip. } \\
\text { super-Y }\end{array}$ & $\begin{array}{l}\text { Norm. } \\
\text { super-Y }\end{array}$ & $\begin{array}{l}\text { Typpir. } \\
\text { super-Y }\end{array}$ \\
\hline $\begin{array}{l}\text { Syysruis ............................ } \\
\text { Winter rye }\end{array}$ & 180 & 2500 & 400 & 150 & & & \\
\hline $\begin{array}{l}\text { Syysvehnä } \\
\text { Winter wheat }\end{array}$ & 210 & 3000 & 450 & 300 & & & \\
\hline $\begin{array}{l}\text { Syysrypsi ..................... } \\
\text { Winte rape }\end{array}$ & 8 & 2000 & & 400 & 500 & & \\
\hline $\begin{array}{l}\text { Kevätvehnä } . . . . . . . . . . . . \\
\text { Spring wheat }\end{array}$ & 270 & 2500 & & & & 500 & \\
\hline $\begin{array}{l}\text { Kaura (rehu) } \ldots . . . . . . . \\
\text { Oat (fodder) }\end{array}$ & 220 & 3250 & & & & 500 & \\
\hline $\begin{array}{l}\text { Ohra (rehu) } \\
\text { Barley (fodder) }\end{array}$ & 200 & 3250 & & & & 500 & \\
\hline $\begin{array}{l}\text { Kuiva heinä } \\
\text { Dry hay }\end{array}$ & & & & & & & \\
\hline$* \begin{cases}\mathrm{tt} & (1 / 3 \times 15) \\
\mathrm{na} & 0 / 3 \times 10)\end{cases}$ & & $\begin{array}{l}5000+ \\
6300 \text { säi }\end{array}$ & iilörehua silc & $\begin{array}{l}300 \\
\text { lage }\end{array}$ & & & 500 \\
\hline $\begin{array}{l}\text { Säilörehu } \\
\text { Silage }\end{array}$ & & & & & & & \\
\hline$* \begin{cases}\text { tt } & (1 / 3 \times 15) \\
\text { na } & (1 / 3 \times 15)\end{cases}$ & & 22000 & & & & & 1000 \\
\hline $\begin{array}{l}\text { Laidun } \\
\text { Pasture }\end{array}$ & & & & & & & \\
\hline$*\left\{\begin{array}{l}\text { pa }(1 / 4 \times 5) \\
\text { tt }(1 / 4 \times 5) \\
\text { na }(1 / 4 \times 15) \\
\text { er }(1 / 4 \times 3)\end{array}\right.$ & & 3000 ry & & & & & 800 \\
\hline * siemenseos: $\begin{array}{ll}\mathrm{tt}=\mathrm{t} \\
\mathrm{na}= \\
& \mathrm{pa}= \\
& \mathrm{er}=\end{array}$ & $\begin{array}{l}\text { timotei } \\
\text { nurminata } \\
\text { puna-apila } \\
\text { englantilain }\end{array}$ & inen raihei & & & & & \\
\hline
\end{tabular}


Maidontuotannossa tuotos on tutkimuksessa ollut $4750 \mathrm{~kg}$ 4-prosenttista maitoa lehmää kohti. Karjan uudistusprosentiksi on otettu 25 ja lypsykarjan keskimääräiseksi poikimisluvuksi 1,05 vasikkaa lehmää kohti. Ruokinta on laskettu normien perusteella edellyttäen, että lehmän keskielopaino on $500 \mathrm{~kg}$. Säilörehu on ruokinnassa keskeinen; sen osuus on $900 \mathrm{~kg}$ ja heinän osuus 850 kg lehmää ja vuotta kohti.

\subsection{Tuotantoteknilliset tasot}

Malleissa tuotanto voi tapahtua kahdella teknisellä tasolla. Pääomantarve on eri tasoilla erilainen ja työn määrä korkeammalla tasolla luonnollisesti vähäisempi. Aikaisempien tutkimusteni perusteella (WECKMAN 1972) on voitu todeta, että tutkimusalueen viljelijät jo nyt varsin yleisesti soveltavat malleissa käytettyä alempaa tuotantotekniikkaa käytäntöön. Kuitenkaan ei voida väittää, että tilanne keskimäärin olisi tällainen. Voidaan kuitenkin karkeasti arvioida, että puolet viljelijöistä jo tällä hetkellä käyttää tätä tuotantotekniikkaa.

Ainoastaan muutamat harvat viljelijät soveltavat tällä hetkellä ylempää tuotantotekniikkaa.

Tuotantotekniikan erot eivät kuvastu tuotostasolta, jotka pysyvät muuttumattomina kaikissa malleissa. Tämä perustuu siihen, että muiden panosten määrät pysyvät muuttumattomina siirryttäessä toiselta tuotantotekniseltä tasolta toiselle.

\subsection{Y ritysten koko}

Niin kuin aikaisemmin on mainittu, malliyritysten kokoa ei rajoiteta muulla kuin työpanoksella. Tarkoituksenani on lähinnä tutkia yhden, kahden ja kolmen perheen työpanoksia vastaavia tilanteita. Työtuntimäärät ovat mainituissa tapauksissa 2500, 5000 ja 7500 tuntia vuodessa. Nämä työpanokset voidaan kokonaan sijoittaa maatalouteen. Perheiden kokonaistyöpanokseen kuuluvat kuitenkin mainittujen tuntimäärien lisäksi myös metsä- ja kotitalouden vaatimat työpanokset. Maanviljelijän tekemä suunnittelu-, tarkkailuja toimistotyö ei myöskään sisälly ilmoitettuihin tuntimääriin.

Taulukko 2. Käytettävissä olevat työtuntimäärät kasvukauden työhuippujen aikana.

Table 2. Manhours available during peaks of growing season.

\begin{tabular}{|c|c|c|c|}
\hline \multirow{2}{*}{$\begin{array}{l}\text { Kokonaistyö- } \\
\text { tuntimäärä } \\
\text { Total number } \\
\text { of man-hours }\end{array}$} & \multicolumn{3}{|c|}{$\begin{array}{l}\text { Työtuntien enimmäismäärä työhuippujen aikana } \\
\text { Maximum number of man-hours during peak season }\end{array}$} \\
\hline & $\begin{array}{l}\text { Kevät (15 päivää) } \\
\text { Spring ( } 15 \text { days) }\end{array}$ & $\begin{array}{l}\text { Keskikesä (15 pv) } \\
\text { Summer (15 days) }\end{array}$ & $\begin{aligned} \text { Syksy }(40 \mathrm{pv}) \\
\text { Autumn }(40 \text { days })\end{aligned}$ \\
\hline 2500 & 225 & 225 & 600 \\
\hline 5000 & 450 & 450 & 1200 \\
\hline 7500 & 675 & 675 & 1800 \\
\hline
\end{tabular}

Työhuippujen pituudet on arvioitu tutkimusalueen sää- ym. olosuhteita vastaaviksi. 
Maataloudessa on työvoimatarpeen kausivaihtelu verraten suuri. Etenkin kasvinviljelyssä esiintyy varsin jyrkkiä työhuippuja kasvukauden aikana. Työhuiput on otettu huomioon tilamalleissa perinteellisellä tavalla siten, että käytettävissä olevien työtuntien enimmäismäärä työhuippujen aikana on arvioitu kokonaistyötuntimäärän perusteella. Arvioinnin tulos eri vaihtoehtojen mukaan käy ilmi seuraavasta taulukosta.

\subsection{Tuotantosuunnat}

Tutkimuksessa vertailen keskenään kahta erikoistunutta päätuotantosuuntaa, nimittäin maidontuotantoa ja karjatonta taloutta. Lisäksi tulen pohtimaan myös naudanlihatuotannon edellytyksiä. Naudanlihantuotantoa voidaan tilamalleissa harjoittaa joko erillisenä tuotannonhaarana tai maidontuotantoon yhdistettynä. Se, että juuri mainitut tuotantosuunnat ovat tutkimuksen kohteena, johtuu lähinnä niiden yleisestä tärkeydestä tutkimusalueella. Viime vuosien aikana on melko yleisesti siirrytty karjattomaan talouteen niillä seuduilla, joilla aikaisemmin tuotettiin runsaasti maitoa. Osaksi tästä syystä esiintyy aika ajoin vaikeuksia varsinkin pääkaupungin kulutusmaitohuollossa. Tutkimukseni pyrkii selvittämään lisätyn maidontuotannon liiketaloudellisia mahdollisuuksia tutkimusalueella.

Erikoistuttaessa karjattomaan talouteen voidaan tilamalleihin sisällyttää seuraavat tuotantohaarat: syysvehnä, syysrukiin, syysrypsin, kevätvehnän, kauran ja ohran tuotanto.

Erikoistuneeseen maidon- ja naudanlihan tuotantoon liittyy aina tarpeellinen karkearehun viljely. Mallissa on edellytetty, että viljelijä levittää lannan omalle pellolle.

Olisi luonnollisesti ollut mielenkiintoista tutkia muitakin erikoistuneita tuotantosuuntia. Onhan tutkimusalue luontaisilta edellytyksiltään erittäin edullinen verrattuna maan muihin maatalousalueisiin. Tämän tutkimuksen yhteydessä ei kuitenkaan varojen niukkuuden takia ole ollut mahdollista tutkia muita vaihtoehtoja. 


\section{Numeroaineiston sovittaminen MC-menetelmää varten}

Yhtenä tärkeänä MC-menetelmän etuna voidaan pitää sitä, että tuotannon laajuusvaikutukset (scale effects) voidaan määrätyllä tavalla ottaa huomioon malleissa. Panosten käyttö tuotosyksikköä kohti on esimerkiksi maataloudessa riippuvainen tuotannon laajuudesta. Malleissa on yllä kuvatut vaikutukset otettu huomioon mahdollisuuksien mukaan lineaarisissa funktioissa siten, että niihin on lisätty vakio seuraavan esimerkin mukaisesti:

$$
\begin{aligned}
& y=q+a x \\
& y=\text { kokonaistulos } \\
& q=\text { vakio } \\
& a=\text { panosmäärä yksikköä kohti } \\
& x=\text { panosten lukumäärä }
\end{aligned}
$$

Kuvattu funktio voidaan esittää graafisesti seuraavalla tavalla:

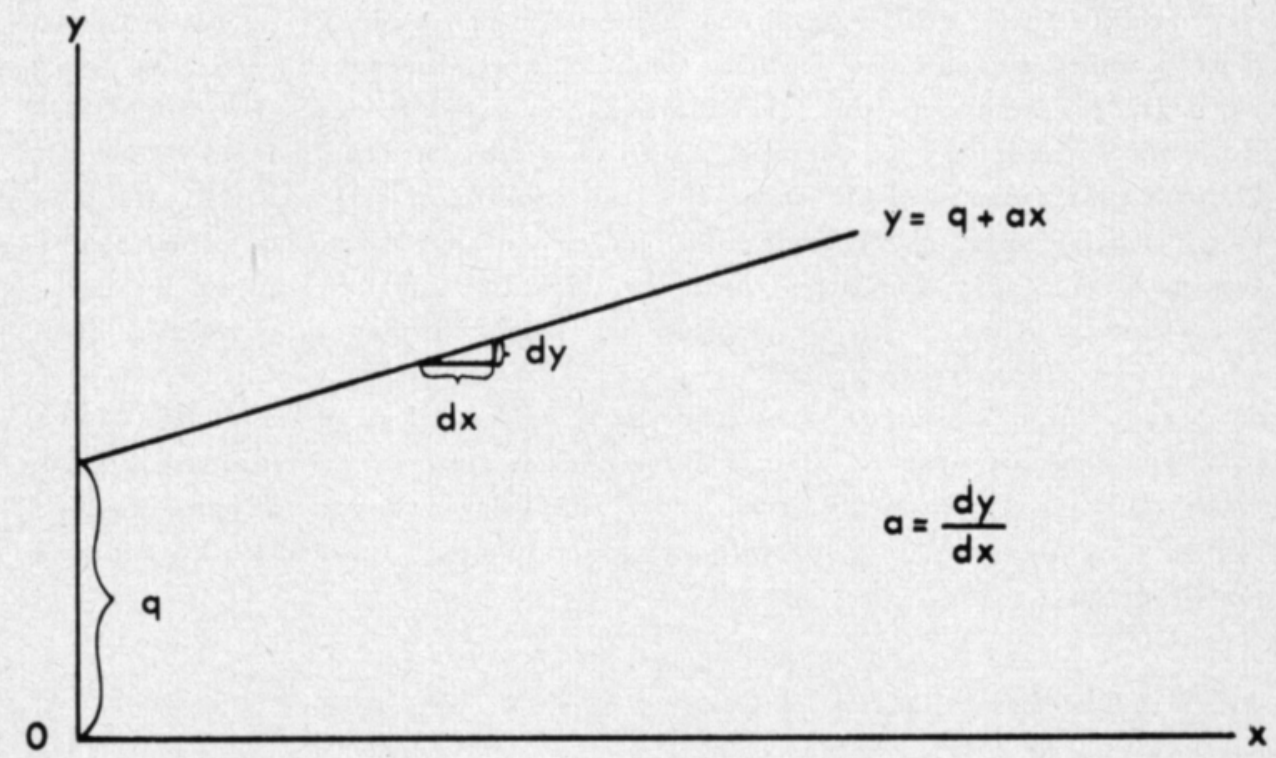

Kuvio 2.

Fig. 2.

Tämäntyyppinen funktio pystyy luonnollisesti edelleen vain kaavamaisesti kuvaamaan niitä laajuusvaikutuksia, jotka esiintyvät maataloudessa, mutta parannus on kuitenkin ilmeinen verrattuna sellaiseen lineaariseen funktioon, joka kulkee diagrammissa origon kautta. 

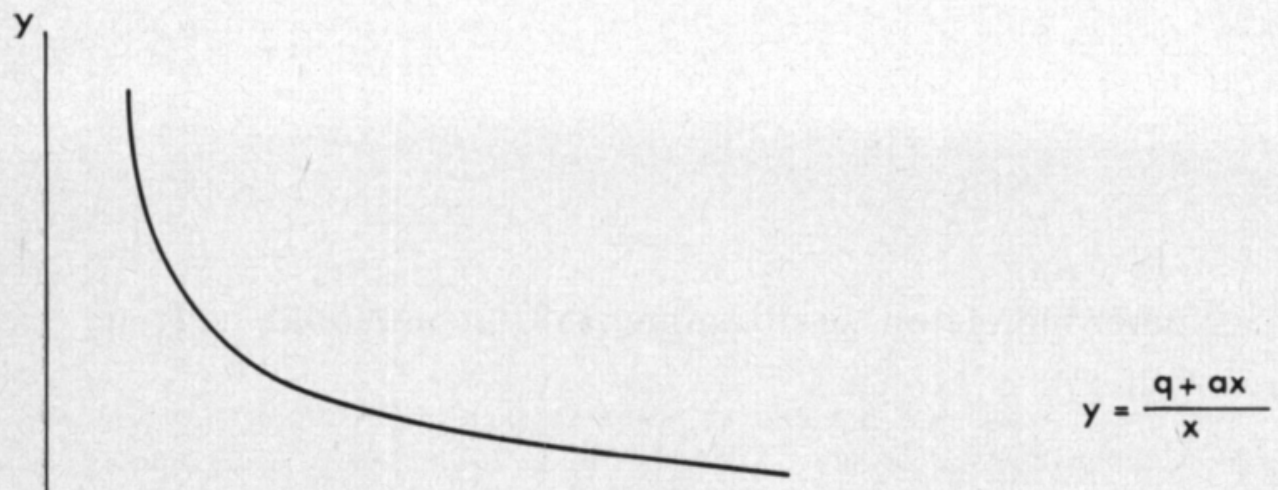

Kuvio 3.

Fig. 3.

Ilmeistä on kuitenkin myös, että lähtölukujen vaatimukset kasvavat. Voidaksemme käyttää ensin mainittua funktiotyyppiä, meidän on kvantitatiivisesti estimoitava em. laajuusvaikutukset. Näiden lukujen epävarmuus ei saa kasvaa liian suureksi. Suomessa yleisesti maatilatalouden suunnittelussa käytetty on viime vuosien aikana huomattavasti parantunut (WESTERMARCK ja Mattila, 1969), mutta heikkouksia esiintyy edelleen verraten paljon. Vakavin puute on se, että mikään vakinainen elin ei jatkuvasti tarkkaile lukuaineiston ajankohtaisuutta. Täjmän takia suunnittelija joutuu jokaisen tehtävän yhteydessä liian paljon tarkistamaan ja uusimaan yleisistä lukuaineistoa. Aineistossa esiintyy edelleen myös muita puutteita, minkä johdosta tämän tutkimuksen yhteydessä ei ole voitu selvittää tuotannon laajuusvaikutusta kaikkien panosten suhteen. Tärkeimmät seikat ovat ilmeisesti tässä suhteessa rakennus-, kone- ja työpanosten vaihtelut yksikköä kohti tuotannon laajuuden vaihdellessa. Kahden ensin mainitun panoksen suhteen on laajuusvaikutus voitu tyydyttävästi selvittää.

Tämän työn yhteydessä ovat prof. E. H. OKȘANEN ja yliarkkit. E. VÄÄNÄNEN antaneet asiantuntija-apua. Työpanoksen suhteen on laajuusvaikutusta voitu selvittää ainoastaan osittain. Eri panoksia koskevan lukuaineiston perusteella on pienimmän neliösumman menetelmällä estimoitu funktiot panosten käyttöä varten.

\subsection{Rakennuskustannukset}

Rakennuskustannukset on selvitetty maatilahallutuksen rakennustoimiston uudisrakennuksia koskevan aineiston perusteella. Mainostuotannossa on tutkittu kahta erilaista sisustusmenetelmää. Alempaan tuotantotekniseen tasoon on liitetty parsinavetta ja korkeampaan tasoon parsipihatto. Molempiin sisustuksiin kuuluu putkilypsy-, tornisäiliö- ja lietelantajärjestelmä. Tuorerehutornien tyhjennys tapahtuu kouralaitteella 300 tonnista lähtien ja 900 tonnista lähtien automaattisella tornipurkajalla. 
Taulukko 3. Navetan rakennuskustannukset sisustusjärjestelmien ja nautayksikkömäärien mukaan (syksy 1973).

Table 3. Building cost of cow shed as interior and number of cattle varies (autumn 1973).

Nautayksikōt

Rakennuskustannukset, mk Building cost, Fmk

Head of cattle

$\begin{array}{cc}\text { Parsinavetta } & \text { Parsipihatto } \\ \text { Stall stable } & \text { Barn with cow cubicles }\end{array}$

\begin{tabular}{|c|c|c|}
\hline 12 & 83400 & 119200 \\
\hline 33 & 220100 & 263100 \\
\hline 108 & 647600 & 706600 \\
\hline
\end{tabular}

Tämän lukuaineiston perusteella voidaan estimoida lineaarisia funktioita ja tulokseksi saadaan:

Parsinavetta

$$
\mathrm{Y}=24000+6000 \text { ny } \quad \mathrm{Y}=\text { rakennuskustannukset }
$$

Parsipihatto

$$
Y=44300+6128 \text { ny }
$$

Myöskin muiden tarvittavien rakennusten kustannukset selviävät vastaavalla tavalla.

Kalustovaja

$$
Y=7000+400 \text { ha }
$$

Kaavasta käy ilmi, että kalustovajan suuruus riippuu peltoalasta.

Kuivaamo

$$
Y^{\prime}=12000+1600 \text { ha }
$$

Kuivaamon kapasiteetti riippuu kuitenkin viljanviljelyalasta niin, että kaavaa sovelletaan vasta kun viljanviljelyyn käytetty kokonaisala tilalla on kasvannut suuremmaksi kuin 15 ha. Tähän laajuuteen saakka voidaan malleissa käyttää vierasta kuivuria normaalia kuivatusmaksua vastaan.

Lihantuotantorakennus

$$
Y=10000+4500 \text { ny }
$$

Uudistusrakennusten vuotuiset kustannukset ovat poisto, korot ja kunnossapito. Nautakarjasuojan vuotuiset kustannukset ovat arvion mukaan 10 uudisarvosta, josta poistot ovat lähes $5 \%$, kunnossapito hieman yli 1 ja lisäksi pääoman korko. Kalustovajan vuotuiset kustannukset ovat arvion mukaan $9 \%$ ja kuivaamon $13,5 \%$ uudisarvosta.

\subsection{Konekustannukset}

Erityisen tuntuva on ilmeisesti koepääoman laajuusvaikutus mm. jakamattomuusongelmien vuoksi. Konepääoma kasvaa todennäköisesti portaittain kapasiteetin lisääntyessä, varsinkin jos liikutaan jatkuvasti samalla teknisellä tasolla. Esimerkiksi traktoripääoman suuruuden voidaan olettaa kasvavan kuviossa esitetyllä tavalla, mikäli hankitaan aina yhtä suuria traktoreita. 


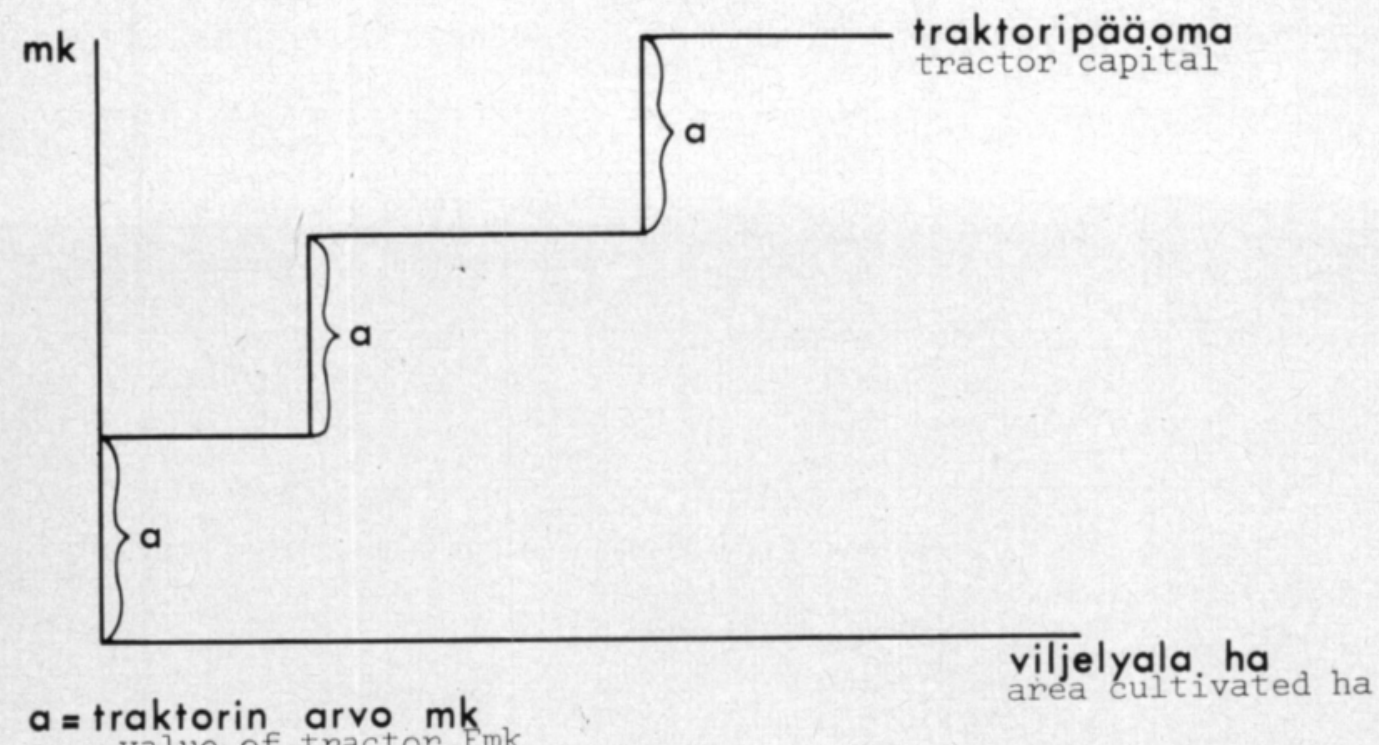

Kuvio 4 .

Fig. 4.

Kuten aikaisemmin on ilmennyt, tässä tutkimuksessa verrataan keskenään kahta erilaista tuotantoteknistä tasoa (I, II). Molempien tasojen konepääoman riippuvuus viljelyalasta on estimoitu lineaaristen funktioiden avulla.

Tarvittavat koneet on jaettu eri tasoilla kolmeen ryhmään, nimittäin peruskoneisiin, viljanviljelyn erikoiskoneisiin ja nurmiviljelyn erikoiskoneisiin. Koneiden arvot on määritetty syksyllä 1973 vallinneiden vähittäishintojen mukaan.

\section{T a so I}

Taulukko 4. Tarvittavien peruskoneiden arvon kehitys peltoalan kasvaessa. Taso I.

Table 4. The development of value of basic machines as the area of cultivated land increases. Mechanization level $I$.

\begin{tabular}{|c|c|c|c|}
\hline \multirow{2}{*}{$\begin{array}{l}\text { Peruskoneet } \\
\text { Basic machines }\end{array}$} & \multicolumn{3}{|c|}{$\begin{array}{c}\text { Peruskoneiden arvot, } \mathrm{mk} \\
\text { Value of basic machines, } \mathrm{Fmk}\end{array}$} \\
\hline & $0-25$ ha & $25-50$ ha & $50-100$ ha \\
\hline Traktori - Tractor .............................. & 32500 & 65500 & 97500 \\
\hline Aurat $3 \times 14 "$ - Ploughs ....................... & 2677 & 5354 & 8031 \\
\hline 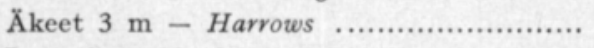 & 2000 & 2000 & 4000 \\
\hline Lannoitteen levittäjä $2,5 \mathrm{~m} \ldots \ldots \ldots \ldots \ldots \ldots \ldots \ldots \ldots$ & 2768 & 2768 & 2768 \\
\hline \multicolumn{4}{|l|}{ Fertilizing machine } \\
\hline Kylvökone $2,5 \mathrm{~m}$ - Seeder ..................... & 3500 & 3500 & 3500 \\
\hline Jyrä 3,5 m - Roller ............................ & 1200 & 1200 & 1200 \\
\hline Rikkaruohoruisku $9 \mathrm{~m}$ Weed sprayer ........ & 1600 & 1600 & 1600 \\
\hline Peräkärryt - Two-wheeled trailer ............. & 2400 & 4800 & 7200 \\
\hline Yhteensä - Total ....... & 48645 & 86222 & 125799 \\
\hline
\end{tabular}


Taulukko 4:n aineiston perusteella on muodostettu kolme havaintoparia:

$\mathrm{X}$

Havainto

Observation

1

2

3
Peltoala, ha

Field area, ha

12.5

37.5

75.0
Y

Konepääoma, $\mathrm{mk}$

Capital in machinery, Fmk

48645

86222

125799

Tämän aineiston perusteella estimoidaan edelleen lineaarinen funktio:

$$
\mathrm{Y}=36042+1220 \text { ha }
$$

$y$-arvon standardipoikkeama Sy $=5446$.

Lasketun standardipoikkeaman mukaan funktio kuvaa melko hyvin peruskoneiden arvon kehitystä peltoalan kasvaessa. Kuitenkin on todettava, että $\mathrm{X}$-arvot on valittu peltosuuruusluokkien keskiväliltä, mikä tässä tapauksessa vähentää Y-arvojen standardipoikkeaman merkitystä ratkaisevasti.

Kuvatulla tavalla voidaan estimoida vastaavanlaisia funktioita nurmiviljelyn erikoiskokeita varten. Kyseisellä teknisellä tasolla nämä koneet ovat:

Niittokone 6 '

Viistoharava $1,8 \mathrm{~m}$

Kovapaalaaja

Kelasilppuri

Murskain 6'

Funktio saa muodon:

$$
\begin{aligned}
& \mathrm{Y}=3500+700 \mathrm{X} \\
& \mathrm{X}=\text { ha nurmiviljelyssä }
\end{aligned}
$$

Viljanviljelyn erikoiskone on leikkuupuimuri. Tämän koneen arvo viljanviljelyalan funktiona on:

$$
\begin{aligned}
& \mathrm{Y}=22500+900 \mathrm{X} \\
& \mathrm{X}=\text { ha viljanviljelyssä }
\end{aligned}
$$

Kyseisellä teknisellä tasolla on leikkuupuimurin työleveys $8^{\prime}$.

T a s o I I

Ainoastaan muutamat harvat viljelijät ovat tutkimusalueella ottaneet käytäntöön malleissa esitetyn korkeimman tuotantotekniikan. Peruskoneistus on tällä tasolla seuraavanlainen:

$\begin{array}{ll}\text { Traktori } & 80-100 \mathrm{hv} \\ \text { Aurat } & 4 \times 14^{\prime \prime} \\ \text { Äkeet } & 5 \mathrm{~m} \\ \text { Yhdistelmäk. } & 4 \mathrm{~m} \\ \text { Rikkaruohoruisku } 13 \mathrm{~m} \\ \text { Peräkärryt } & 8 \mathrm{t}\end{array}$

Tässä tapauksessa voidaan hintatietojen perusteella arvioida neljä havaintoparia.

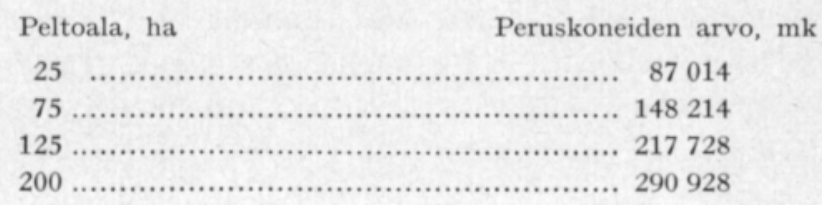


Havaintoparien perusteella estimoitu funktio on muodoltaan:

$$
\mathrm{Y}=61058+1176 \mathrm{X}
$$

Kuten huomataan, on vakio tällä teknisellä tasolla ratkaisevasti suurempi ja peltoalan mukaan vaihteleva osuus arvosta jonkin verran alhaisempi kuin edellisellä tasolla.

Nurmiviljelyn erikoiskoneiden arvon funktio on:

$$
\begin{aligned}
& \mathrm{Y}=8670+350 \mathrm{X} \\
& \mathrm{X}=\text { ha nurmiviljelyssä }
\end{aligned}
$$

Viljanviljelyn erikoiskoneen, leikkuupuimurin, työleveys on kyseisellä tasolla 14' ja arvo viljanviljelyalan funktiona:

$$
\begin{aligned}
& \mathrm{Y}=40000+533 \mathrm{X} \\
& \mathrm{X}=\text { ha viljanviljelyssä }
\end{aligned}
$$

\subsection{Työnkäyttöluvut}

Työnkäytön suhteen on laajuusvaikutusta tämän tutkimuksen yhteydessä voitu selvittää ainoastaan osittain. Kasvinviljelystä ei ole toistaiseksi saatavana tarpeeksi eriteltyjä lukuja, jotta tarvittavat laskelmat voitaisiin suorittaa. Tuotannon laajuusvaikutukset nautakarjatalouden työnkäytön suhteen on kuitenkin voitu tyydyttävästi arvioida. Tässä arvioinnissa on luonnollisesti otettu huomioon kasvintuotannossa esiintyvät työhuiput. Maidontuotannon työnkäyttö on arvioitu maatilahallituksen rakennustoimiston käyttämien normilukujen perusteella. Seuraavat päätyövaiheet kuuluvat tähän työhön:

Ruokinta

Lypsäminen

Puhdistustyöt

Muut työt

Ryhmän muut työt lasketaan talouskeskuksen rehunkuljetustyöt, jauhatustyöt, navetan peruspuhdistus, keinosiemennys ja poikimistyöt, eläinten tarkkailu yms.

Estimoidut funktiot maidontuotannon työnkäyttöä varten ovat eri tasoilla seuraavat:

$$
\begin{array}{ll}
\text { Parsinavetta } & \text { Parsipihatto } \\
Y=250+59 \text { ny } & Y=220+40 \text { ny }
\end{array}
$$

Kyseisten funktioiden vakiot ovat suhteellisen pieniä, mikä osoittaa sen seikan, että laajuusvaikutus maidontuotannon työnkäyttöön ei ole kovinkaan suuri.

Seuraavassa taulukossa on kasvituotannon työntarve laskettu yksinomaan hehtaaria kohti, vaikka laajuusvaikutuksia esiintyy käytännössä myöskin tällä alalla. Käytettävissä oleva lukuaineisto ei kuitenkaan tällä hetkellä anna mahdollisuuksia näiden vaikutusten huomioon ottamiseen. Tutkimuksessa on yritetty välttää suurimmat virheet sallimalla ainoastaan puoltatoista hehtaaria suuremmat viljelyalat eri viljakasveille. 
Taulukko 5. Työntarve (t/ha) kasvintuotannossa eri jaksojen aikana kummallakin tekniikan tasolla.

Table 5. Labour requirement in plant production (h/ha) during different periods and on different techical levels.

\begin{tabular}{|c|c|c|c|c|c|c|c|c|c|c|c|}
\hline & $\begin{array}{l}\text { Jakso } \\
\text { Period }\end{array}$ & $\begin{array}{l}\text { Syysv } \\
\text { Winter }\end{array}$ & $\begin{array}{l}\text { ehnä } \\
\text { wheat }\end{array}$ & $\begin{array}{l}\text { Syy } \\
\text { Wint }\end{array}$ & $\begin{array}{l}\text { sruis } \\
\text { ter rye }\end{array}$ & $\begin{array}{l}\text { Syy } \\
\text { Wint }\end{array}$ & $\begin{array}{l}\text { srypsi } \\
\text { ter rape }\end{array}$ & $\begin{array}{l}\text { Kevät } \\
\text { Sprin }\end{array}$ & $\begin{array}{l}\text { t tvehnä } \\
g \text { wheat }\end{array}$ & & $\begin{array}{c}\text { Kaura } \\
\text { Oat }\end{array}$ \\
\hline & & $\begin{array}{c}\text { Taso } \\
\text { I }\end{array}$ & $\begin{array}{c}\text { Lelev } \\
\text { II }\end{array}$ & $\begin{array}{c}\text { Taso } \\
\text { I }\end{array}$ & $\begin{array}{c}\text { Level } \\
\text { II }\end{array}$ & $\begin{array}{c}\text { Taso } \\
\text { I }\end{array}$ & $\begin{array}{c}\text { Level } \\
\text { II }\end{array}$ & $\begin{array}{c}\text { Taso } \\
\text { I }\end{array}$ & $\begin{array}{c}\text { Level } \\
\text { II }\end{array}$ & $\begin{array}{c}\text { Taso } \\
\text { I }\end{array}$ & $\begin{array}{c}\text { Level } \\
\text { II }\end{array}$ \\
\hline & & & & & & & & & & $M$ & \\
\hline Kevät & - Spring ....... & 0.6 & 0.4 & 0.6 & 0.4 & 4.7 & 3.8 & 7.9 & 5.4 & 7.9 & 5.4 \\
\hline Syksy & - Autumn .... & 15.5 & 10.6 & 16.5 & 10.6 & 13.4 & 10.8 & 8.0 & 5.5 & 8.0 & 5.5 \\
\hline Vuosi & - Year ......... & 22.0 & 15.0 & 22.0 & 15.0 & 25.0 & 20.0 & 22.0 & 15.0 & 22.0 & 15.0 \\
\hline & Jakso & Ohra & Barley & Hei & inä & Hay & Säilörehu & Silage & e Laid & lun & Pasture \\
\hline & Period & Taso & Level & Tas & & Level & Taso & Level & Tas & & Level \\
\hline & & I & II & I & & II & I & II & I & & II \\
\hline Kevät & - Spring ....... & 7.9 & 5.4 & & 1 & 1.7 & 3.8 & 2.7 & 1. & 1 & 0.8 \\
\hline Syksy & - Autumn .... & 8.0 & 5.5 & & 3.0 & 5.6 & 8.0 & 5.6 & & & \\
\hline Vuosi & - Year ........ & 22.0 & 15.0 & 32. & & 22.7 & 54.2 & 37.9 & 14. & & 9.8 \\
\hline
\end{tabular}

Työnkäytössä huomataan selvä ero eri tasojen välillä. Jälleen on syytä huomauttaa, että tuotantotekniikan tasojen erot ilmenevät malleissa yksinomaan erilaisina työn- ja pääomatarpeena.

\subsection{Kannattavuuden ilmaiseminen}

Tilamallit on konstruoitu siten, että ne osoittavat suoraan yrityksen kykyä maksaa palkkaa viljelijäperheen työstä. Palkka on ilmoitettu markkoina työtuntia kohti. Kokonaistuotosta on vähennetty kaikki muut kustannukset. Kone- ja rakennuspääoman vuotuiset kustannukset on oletettu maksetuiksi samoin kuin pellon "korko" $300 \mathrm{mk} / \mathrm{ha}$.

\subsection{Mallien konstruoiminen ja ratkaisumenettely}

MC-menetelmän mallitekniikka muistuttaa verraten paljon lineaarisen ohjelmoinnin mallitekniikkaa. Yritysmalli konstruoidaan matriisimuotoon ja sisältää kohdefunktion, jonka mukaan tulos lasketaan variaabelien saatua satunnaiset arvonsa. Rajoitukset voidaan kirjoittaa yhtälö- tai epäyhtälömuotoon, missä rajoittavat panokset ovat esim. oikealla ja panoskulutus tuoteyksikköä kohti vasemmalla puolella. Tavanomaiset osto- ja myyntiaktiviteetit liitetään matriisiin riippuvaisten aktiviteettien muodossa. Viime aikoina on otettu käyttöön kolmas aktiviteettiryhmä, nimittäin panoksia tuottavat aktiviteetit. Christensen (1970) osoittaa, että näiden aktiviteettien avulla voidaan esim. ratkaista sellaiset mallitekniset ongelmat, jotka johtuvat siitä, että maatilatalouden tuotteista osa on ns. välituotteita, jotka käytetään edelleen panoksina tuotannossa. Esimerkkeinä voidaan mainita karkearehu, porsaat ym. Voidaan kui- 


\begin{tabular}{|c|c|c|c|c|c|c|c|c|c|c|c|}
\hline \multirow[t]{2}{*}{ Sarake } & \multirow[t]{2}{*}{ N:o } & \multirow{2}{*}{$\begin{array}{c}1 \\
-571\end{array}$} & \multirow{2}{*}{$\begin{array}{c}2 \\
-448\end{array}$} & \multirow{2}{*}{$\begin{array}{c}3 \\
-561\end{array}$} & \multirow{2}{*}{$\begin{array}{c}4 \\
-505\end{array}$} & \multirow{2}{*}{$\begin{array}{c}5 \\
-473\end{array}$} & \multirow{2}{*}{$\begin{array}{c}6 \\
3373\end{array}$} & \multirow{2}{*}{$\begin{array}{c}7 \\
1136\end{array}$} & \multirow{2}{*}{$\begin{array}{c}8 \\
-22\end{array}$} & \multirow{2}{*}{$\begin{array}{c}9 \\
-596\end{array}$} & \multirow{2}{*}{$\begin{array}{r}10 \\
-410\end{array}$} \\
\hline & & & & & & & & & & & \\
\hline \multicolumn{12}{|c|}{ Rivi N:o } \\
\hline (1) & $225 \geqq$ & 7.9 & 7.9 & 0.6 & 0.6 & 4.7 & $10.20 / 4.91$ & 2.96 & & & \\
\hline (2) & $225 \geqq$ & & & & & & $10.20 / 6.68$ & 6.14 & & & \\
\hline (3) & $600 \geqq$ & 8 & 8 & 15.5 & 16.5 & 13.4 & $20.40 / 10.03$ & 6.20 & & & \\
\hline (4) 2 & $2500 \geqq$ & 22 & 22 & 22 & 22 & 30 & $250 / 98.58$ & 58.36 & 5.3 & & \\
\hline (5) & & & & & & & -0.56 & -0.10 & & 1 & \\
\hline (6) & & & & & & & -0.35 & & & & . 1 \\
\hline (7) & & -25.0 & & -30.0 & & & & & & & \\
\hline (8) & & & & & -25.00 & & & & & & \\
\hline (9) & & & & & & -15.0 & & & & & \\
\hline (10) & & -2.50 & -32.50 & -2.50 & -2.50 & & 3.27 & 12.20 & & & \\
\hline (11) & & & & & & & -0.8 & 1.0 & & & \\
\hline (12) & & & & & & & 1.15 & & & & \\
\hline (13) & & & & & & & & 1 & & & \\
\hline (14) & & 1 & 1 & 1 & 1 & 1.5 & 1.05 & 0.1 & 0.5 & . & \\
\hline (15) & & 1 & 1 & 1 & 1 & 1 & & & & & \\
\hline (16) & & 1 & 1 & 1 & 1 & 1.5 & 0.53 & 0.05 & 0.5 & & \\
\hline (17) & & 1 & 1 & 1 & 1 & 1 & & & & & \\
\hline (18) & & & & & & & 0.56 & 0.10 & & & \\
\hline (19) & & 1 & 1 & 1 & 1 & 2 & 1.05 & 0.1 & 1 & & \\
\hline (20) & & 171 & 134 & 336 & 302 & 207 & 900 & 654 & & & \\
\hline (21) & & & & & & & 2050 & 800 & & & \\
\hline (22) & & & & 0.5 & 0.5 & -1 & -0.28 & -0.03 & -1 & & \\
\hline (23) & & 1.0 & 1.0 & 1.0 & 1.0 & 2 & 10 & 10 & 0 & & \\
\hline (24) & & 100 & 100 & 100 & 100 & 100 & 150 & 300 & 100 & & \\
\hline
\end{tabular}

tenkin myös muodostaa yhdistettyjä tuotannonhaaroja siten, että esim. karkearehutuotanto sidotaan maidontuotantoon samaksi aktiviteetiksi. Viimeksi mainittua menettelytapaa on käytetty tässä tutkimuksessa, kuten selviää sitä MC-matriisista, joka tutkimuksessa käytettyjen tilamallien esimerkkinä seuraavassa esitetään. On kuitenkin myönnettävä, että muodostamalla useita komplisoituja, yhdistettyjä, aktiviteetteja, voidaan sulkea poiss ellaisia malliratkaisuja, jotka voisivat hyvin kilpailla muiden kanssa. Tätä ongelmaa ei kuitenkaan ole ratkaistu täysin panoksia tuottavien aktiviteetien avullakaan.

Mallien konstruoiminen on tämän takia suoritettava erittäin huolellisesti, jotta edellä mainituista virheistä vältyttäisiin.

Mm. Lindgren ja Carlsson (1966) sekä Christensen (1970) ovat kirjoituksissaan seikkaperäisesti käyneet läpi MC-menetelmän ratkaisualgoritmin, jonka liiketaloustieteellinen sovellutus on Ruotsin korkeakoulussa tapahtuneen ryhmätyön tulos. Ryhmään kuuluivat prof. I. Lindgren, CTH. Göteborg, agr. B. Hovmark, Uppsala sekä lis. M. Carlsson, Alnarp. Samantyyppistä satunnais- 


\begin{tabular}{rrrrrrrrrrrrrrrrr}
\hline Sar. N:o & 11 & 12 & 13 & 14 & 15 & 16 & 17 & 18 & 19 & 20 & 21 & 22 & 23 & 24 & 25 & 26 \\
& & & & & & -2400 & -1000 & -630 & -1620 & -5646 & -3825 & -595 & & & & \\
62 & 70 & 97 & 46 & 300 & 600 & 450 & 36 & 216 & 210 & 153 & 119 & 300 & 0.08 & 0.08 & \\
& & & 42 & 50 & & & & & & & & & & \\
\hline
\end{tabular}

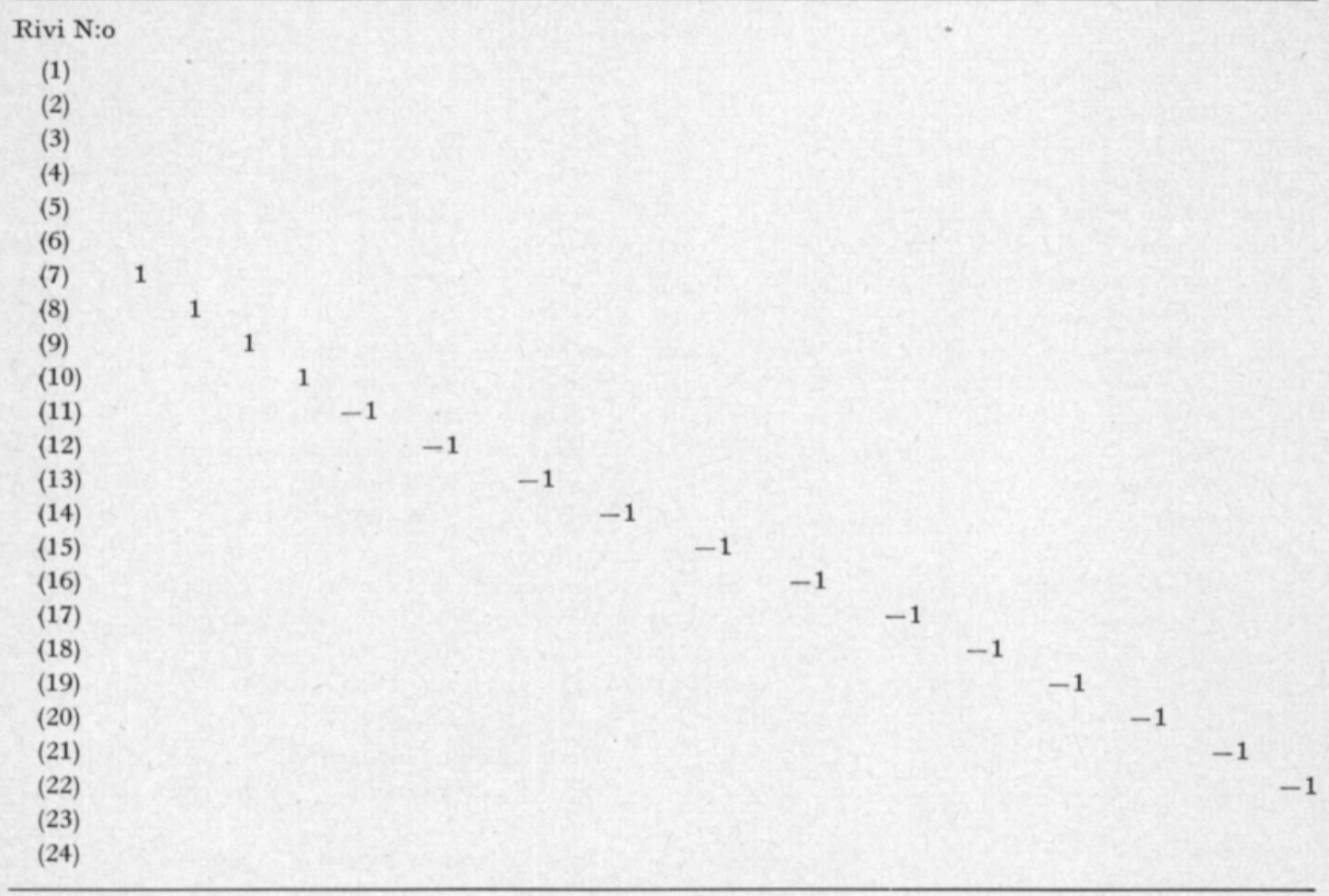

lukumenettelyä on aikaisemmin käytetty mm. fysiikan eräiden tutkimusten yhteydessä, kun on haluttu paikallistaa maksimi- tai minimitilanteita sekä niitä välittömästi ympäröiviä tilanteita (CARLsson 1970). Liiketaloustieteessä menetelmää käytettiin kuitenkin ensimmäisen kerran yllä mainitun ryhmätyön yhteydessä. Kyseessä olevan algoritmin ohjelmoiminen tietokonetta varten on menetelmän käytön edellytys. Ohjelma saatiin Suomeen ensimmäisen kerran tätä tutkimusta varten Maatalouden Laskentakeskukseen, Tikkurilaan, missä ko. tilamallit ratkaistiin. Ohjelma on jälkeenpäin sovitettu myös Helsingin yliopiston laskentakeskuksen tietokonetta varten. Myös Englannissa on kehitetty MC-menetelmän tietokoneohjelma (Donaldson ja Webster 1967). Menetelmää on siellä myös kokeilumielessä käytetty rehusekoitusongelman ratkaisussa (DENT ja Thомpson 1967). Menetelmän eräänä varjopuolena pidetään yleisesti sitä, että suurempien matriisien ratkaiseminen muodostuu helposti vaivalloiseksi. Tämän tutkimuksen matriisien keskikoko oli 25 saraketta ja 25 riviä. Tämänkokoisten matriisien ratkaisu ei tuottanut mainittavia vaikeuksia. 
RIVI- JA SARAKESELITYKSET

\begin{tabular}{|c|c|c|}
\hline vi & Selitys & Yksikl \\
\hline 1 & Työ kevät ... & $\mathrm{t}$ \\
\hline 2 & , kesä ................... & \\
\hline 3 & , syksy …............. & \\
\hline 4 & . vuosi ................. & \\
\hline 5 & Nurmiala .................. & ha \\
\hline 6 & Laidunala ................ & ha \\
\hline 7 & Kevät- ja syysvehnä & $100 \mathrm{~kg}$ \\
\hline 8 & Ruis ............................. & $100 \mathrm{~kg}$ \\
\hline 9 & Rypsi ....................... & $100 \mathrm{~kg}$ \\
\hline 10 & Rehuvilja .................. & $100 \mathrm{~kg}$ \\
\hline 11 & Pikkuvasikka ............ & kpl \\
\hline 12 & Navetta .................... & lehmäpaikka \\
\hline 13 & Lihatuotantorakennus & eläinpaikka \\
\hline 14 & Kalustovaja .............. & ha \\
\hline 15 & Kuivaamo .................. & vilja-ala ha \\
\hline 16 & Peruskoneet .............. & ha \\
\hline 17 & Viljanviljelyn erikois- & \\
\hline 18 & $\begin{array}{l}\text { koneet ..................... } \\
\text { Nurmiviljelyn erikois- }\end{array}$ & vilja-ala ha \\
\hline & koneet...$\ldots \ldots \ldots \ldots \ldots \ldots$ & a ha \\
\hline 19 & Pelto ........................ & ha \\
\hline 20 & Käyttöpääoma .......... & $\mathrm{mk}$ \\
\hline 21 & Eläinpääoma ........... & $\mathrm{mk}$ \\
\hline 22 & Syysviljan kylvöala ... & ha \\
\hline 23 & Minimirajoitus & \\
\hline 24 & Maksimirajoitus & \\
\hline
\end{tabular}

Sarake No Selitys

Kevätvehnä

Rehuvilja (kaura $50 \%$, ohra $50 \%$ )

Syysvehnä

Syysruis

Syysrypsi + kesanto

Lypsylehmá + uudistus + nurmirehu

7 Lihaeläin + nurmirehu

8 Kesanto

9 Nurmiviljelyn kustannukset

10 Jaaidunviljelyn kustannukset

11 Vehrän myynti

12 Rukiin myynti

13 Rypsin myynti

14 Rehuviljan osto/myynti

15 Vasikan osto/myynti

16 Navetan vuotuiset kustannukset

17 Lihantuotantorakennuksen vuotuiset kustannukset

18 Kalustovajan vuotuiset kustannukset

19 Kuivaamon vuotuiset kustannukset

20 Peruskoneiden vuotuiset kustannukset

21 Viljanviljelyn erikoiskoneiden vuotuiset kustannukset

22 Nurmiviljelyn erikoiskoneiden vuotuiset kustannukset

23 Pellon vuokra

24 Käyttōpääoman vuotuise` kustannukset

25 Eläinpääoman vuotuiset kustannukset

26 Kesannon säätelyaktiviteetti 


\section{Ratkaisujen tulokset}

Jokainen tilamalli ratkaistiin MC-menetelmällä 1000 kertaa, eräitä poikkeuksia lukuunottamatta, joiden kohdalla ratkaisujen lukumäärä oli suurempi. Lajittelun jälkeen tietokone kirjoitti 30 parasta tulosta. CARLSSON $(1970$, p. 11) toteaa, että muuttujien lukumäärä mallissa vaikuttaa etsintäprosessin tehokkuuteen. Näin ollen muuttujien lukumäärän kasvaessa tarvitaan yhä useampia ratkaisuja, jotta paras ratkaisu olisi lähellä optimitulosta. Riippumattomien muuttujien lukumäärä tilamalleissa on keskimäärin 8 ja riippuvien keskimäärin 18. CARLSSONin (1970) suorittamien tutkimusten perusteella 1000 ratkaisua riittää tyydyttävän tuloksen saavuttamiseksi, joskin eräissä harvoissa tapauksissa suurempi lukumäärä voi olla tarpeen. Seuraavassa on esitetty jokaisen mallin paras ratkaisu. Yleensä saman mallin parhaat ratkaisut poikkeavat melko vähän toisistaan, mikä koskee sekä työkorvausta että tuotannonhaarojen esiintymistä ja laajuutta. Voidaan hyvinkin olettaa, että esitetyt ratkaisut ovat joko optimaalisia tai lähellä sitä.

\subsection{Erikoistunut maidontuotanto}

Erikoistunut maidontuotanto osoittautui parhaaksi tuotantosuunnaksi, koska se antoi parhaan taloudellisen tuloksen kaikissa niissä tilanteissa, joissa vaihtoehtoiset tuotantosuunnat voivat vapaasti kilpailla keskenään. Erikoistuminen on viety niin pitkälle kuin malli sallii. Olettamuksena on myös, että tarvittava rehuvilja ostetaan melkein kokonaisuudessaan ja ainoastaan karkearehu viljellään omalla tilalla. Niittonurmien ja laitumien uudistamista varten tarvitaan kuitenkin pieni rehuvilja-ala, mutta on otaksuttu, että tarkoitukseen voidaan käyttää vuokrapuimuria ja että vilja voidaan kuivattaa myös vuokratuilla laitteilla. Malleissa niittonurmien ikä on kolme vuotta ja laidunnurmien neljä vuotta. Lisäksi on otaksuttu, että ainoastaan puolet alasta on uudistettava suojaviljaan.

Karkearehun tuotanto sekä lypsylehmien uudistus on malleissa sidottu maidontuotantoon. Sen sijaan vasikkaylijäämä voidaan malleissa joko myydä tai kasvattaa lihaeläimiksi. Ratkaisujen mukaan lihaeläinten kasvattaminen ei kilpaile maidontuotannon kanssa käytettävissä olevasta työpanoksesta, vaan kaikki ylijäämävasikat myydään. Taulukko 6 osoittaa, että lehmien lukumäärä kasvaa suhteellisesti jonkin verran nopeammin kuin työtunnit siirryttäessä vaihtoehdosta toiseen. Tämä onkin johdonmukaista, kun otetaan huomioon työpanoksen muuttuminen yksikköä kohti maidontuotannon laajuuden kasvaessa. 
Taulukko 6. Tulosyhdistelmä. Maidontuotantoyritykset. Tuotannonhaarojen laajuudet eri teknisillä tasoilla ja työpanoksilla.

Table 6. Results of the calculations. Milk-producing farms Sizes of fields of production on different technical levels and inputs of labour.

\begin{tabular}{|c|c|c|c|c|c|c|}
\hline & \multicolumn{2}{|c|}{$2500 \mathrm{~h}$} & \multicolumn{2}{|c|}{$5000 \mathrm{~h}$} & \multicolumn{2}{|c|}{$7500 \mathrm{~h}$} \\
\hline & $\begin{array}{l}\text { Keskik. } \\
\text { tekn. } \\
\text { Medium } \\
\text { techn. } \\
\text { level }\end{array}$ & $\begin{array}{c}\text { Korkea } \\
\text { tekn. } \\
\text { High } \\
\text { techn. } \\
\text { level }\end{array}$ & $\begin{array}{l}\text { Keskik. } \\
\text { tekn. } \\
\text { Medium } \\
\text { techn. } \\
\text { level }\end{array}$ & $\begin{array}{c}\text { Korkea } \\
\text { tekn. } \\
\text { High } \\
\text { techn. } \\
\text { level }\end{array}$ & $\begin{array}{c}\text { Keskik. } \\
\text { tekn. } \\
\text { Medium } \\
\text { techn. } \\
\text { level }\end{array}$ & $\begin{array}{c}\text { Korkea } \\
\text { tekn. } \\
\text { High } \\
\text { techn. } \\
\text { level }\end{array}$ \\
\hline $\begin{array}{l}\text { Lypsylehmä }+ \text { uudistus }(\mathrm{kpl}) \ldots . \\
\text { Milk cows }+ \text { restocking }\end{array}$ & 22 & 33 & 48 & 69 & 73 & 105 \\
\hline Nurmi (ha) - Grass ............... & 12.32 & 18.48 & 26.88 & 38.64 & 40.88 & 58.80 \\
\hline Laidun (ha) - Pasture ........... & 7.70 & 11.55 & 16.80 & 24.15 & 25.55 & 36.75 \\
\hline Rehuvilja (ha) - Fodder crop... & 3.08 & 4.62 & 6.72 & 9.66 & 10.22 & 14.70 \\
\hline $\begin{array}{l}\text { Kokonaispeltoala (ha) } \ldots . . . . . . . . . \\
\text { Total cultivated area }\end{array}$ & 23.10 & 34.65 & 50.40 & 72.45 & 76.65 & 110.25 \\
\hline
\end{tabular}

Taulukko 7. Maidontuotantoyritysten pääomantarve, $1000 \mathrm{mk}$.

Table 7. Need of capital on milk-producing farms, $1000 \mathrm{Fmk}$.

\begin{tabular}{|c|c|c|c|c|c|c|}
\hline & \multicolumn{2}{|c|}{$2500 \mathrm{~h}$} & \multicolumn{2}{|c|}{$5000 \mathrm{~h}$} & \multicolumn{2}{|c|}{$7500 \mathrm{~h}$} \\
\hline & $\begin{array}{c}\text { Keskik. } \\
\text { tekn. } \\
\text { Medium } \\
\text { techn. } \\
\text { level }\end{array}$ & $\begin{array}{c}\text { Korkea } \\
\text { tekn. } \\
\text { High } \\
\text { techn } \\
\text { level }\end{array}$ & $\begin{array}{c}\text { Keskik. } \\
\text { tekn. } \\
\text { Medium } \\
\text { techn. } \\
\text { level }\end{array}$ & $\begin{array}{c}\text { Korkea } \\
\text { tekn. } \\
\text { High } \\
\text { techn. } \\
\text { level }\end{array}$ & $\begin{array}{l}\text { Keskik. } \\
\text { tekn. } \\
\text { Medium } \\
\text { techn. } \\
\text { level }\end{array}$ & $\begin{array}{c}\text { Korkea } \\
\text { tekn. } \\
\text { High } \\
\text { techn. } \\
\text { level }\end{array}$ \\
\hline $\begin{array}{l}\text { Koko pääomantarve ................. } \\
\text { Total need of capital } \\
\text { Pääoman jakaantuminen } \\
\text { Distribution of capital }\end{array}$ & 435 & 665 & 865 & 1259 & 1279 & 1852 \\
\hline $\begin{array}{l}\text { Rakennuspääoma ................................. } \\
\text { Capital for buildings }\end{array}$ & 192 & 298 & 382 & 567 & 565 & 835 \\
\hline $\begin{array}{l}\text { Konepääoma } \\
\text { Capital for machinery }\end{array}$ & 62 & 97 & 89 & 126 & 115 & 156 \\
\hline $\begin{array}{l}\text { Eläinpääoma } \\
\text { Capital for animals }\end{array}$ & 45 & 68 & 98 & 141 & 150 & 215 \\
\hline $\begin{array}{l}\text { Käyttöpääoma .............................. } \\
\text { Operating capital }\end{array}$ & 20 & 30 & 43 & 62 & 66 & 95 \\
\hline $\begin{array}{l}\text { Pelto- ja perusparannuspääoma } \\
\text { Land and basic improvements }\end{array}$ & 116 & 173 & 252 & 362 & 383 & 551 \\
\hline $\begin{array}{l}\text { Investointitarve } \\
\text { Need of investment } \\
\text { Omaa pääomaa \% koko pää- }\end{array}$ & 223 & 472 & 525 & 903 & 775 & 1320 \\
\hline $\begin{array}{l}\text { Omaa paaomaa } \% \text { koko paa- } \\
\text { omasta ...................................... } \\
\text { Farmer's own capital per centage } \\
\text { of total capital }\end{array}$ & 48 & 29 & 39 & 28 & 39 & 28 \\
\hline
\end{tabular}

Taulukko 7 osoitta, että pääomantarve on kaikissa vaihtoehdoissa suuri. Erityisesti rakennuspääomaa ja myöskin pelto- ja perusparannuspääomaa tar- 
vitaan paljon. Tarvittava pääoma kasvaa luonnollisesti myös siirryttäessä korkeammalle tuotantotekniselle tasolle. Maatilatalouden voidaan todeta olevan suhteellisen pääomavaltainen yritysmuoto silloin kun tuotantoa harjoitetaan sellaisilla tuotantoteknisillä tasoilla kuin malleissa edellytetään.

Taulukko 8. Työansio $(\mathrm{mk} / \mathrm{t})$ erikoistuneessa maidontuotannossa ennen verotusta. Table 8. Yield per man-hour $(m k / h)$ before taxes on specialized milkproducing farms.

\begin{tabular}{|c|c|c|c|c|c|c|}
\hline & \multicolumn{2}{|c|}{$2500 \mathrm{~h}$} & \multicolumn{2}{|c|}{$5000 \mathrm{~h}$} & \multicolumn{2}{|c|}{$7500 \mathrm{~h}$} \\
\hline & $\begin{array}{l}\text { Keskik. } \\
\text { tekn. } \\
\text { Medium } \\
\text { techn. } \\
\text { level }\end{array}$ & $\begin{array}{l}\text { Korkea } \\
\text { tekn. } \\
\text { High } \\
\text { techn. } \\
\text { level }\end{array}$ & $\begin{array}{l}\text { Keskik. } \\
\text { tekn. } \\
\text { Medium } \\
\text { techn. } \\
\text { level }\end{array}$ & $\begin{array}{l}\text { Korkea } \\
\text { tekn. } \\
\text { High } \\
\text { techn. } \\
\text { level }\end{array}$ & $\begin{array}{l}\text { Keskik. } \\
\text { tekn. } \\
\text { Medium } \\
\text { techn. } \\
\text { level }\end{array}$ & $\begin{array}{l}\text { Korkea } \\
\text { tekn. } \\
\text { High } \\
\text { techn. } \\
\text { level }\end{array}$ \\
\hline $\begin{array}{l}\text { Työansio mk käytettävissä olevaa } \\
\text { työtuntia kohti ........................ } \\
\text { Yield per available man-hour Fmk } \\
\text { Työansio mk käytettyä työtuntia }\end{array}$ & 7.98 & 11.08 & 10.90 & 15.28 & 11.69 & 16.67 \\
\hline $\begin{array}{l}\text { kohti } \\
\text { Yield per man-hour used Fmk }\end{array}$ & 8.25 & 11.10 & 10.93 & 15.35 & 11.77 & 16.76 \\
\hline
\end{tabular}

Maataloudessa kannattavuutta on perinteellisesti ilmaistu eri tavoilla laskettujen työansioiden avulla. Tämä johtunee siitä tosiasiasta, että maatalousyrittäjä tai yrittäjäperhe useimmiten sekä omistaa kyseisen yrityksen että sijoittaa työpanoksensa siihen. Yrittäjän on tällöin punnittava sekä pääomalle että työlle saatu korvaus. Vasta sen jälkeen hän voi muodostaa itselleen täydellisen kuvan kannattavuudesta.

Tutkimuksessa on työn korvaus laskettu siten, että panosten kustannukset on arvioitu markkinahintojen perusteella. Vuotuiset kone-, rakennus- ja eläinpääomakustannukset on arvioitu yleisesti käytössä olevien menetelmien mukaan. Sama pätee myös käyttöpääoman suhteen. Pellon arvoa on epäilemättä erittäin vaikea arvioida. Tutkimuksessa on otaksuttu, että käytettävä pelto on salaojitettu ja että se tuotantokyvyltään vastaa tutkimusalueen keskiarvoa. Pellon arvoon sisältyvät myös muut tarvittavat perusparannukset. Tällaisen pellon vuokraksi on malleissa arvioitu $300 \mathrm{mk} / \mathrm{ha}$. Pellon korkona vuokra on esim. $6 \%$, mikäli pellon arvo on $5000 \mathrm{mk} / \mathrm{ha}$. Muutoin on korkokanta laskelmissa ollut $8 \%$. Kun kokonaistuotosta vähennetään yllä mainitut kustannukset, muodostaa saatu erotus työpanoksen korvauksen. Taulukossa 8 työn korvaus on laskettu sekä todella tuotannossa käytetyille että eri vaihtoehdoissa käytettävissä oleville työtunneille.

Taulukon mukaan työn korvaus paranee työpanoksen kasvaessa. Kuitenkin kasvu on alussa nopeinta ja hidastuu työtuntien lisääntyessä, niin kuin kuviosta $\mathbf{5}$ tarkemmin selviää.

Kuviossa on esitettyä käyrää kohti vain kolme havaintoa. Mikäli oletetaan, että työpanoksen ja työn korvauksen suhde kehittyy täysin johdonmukaisesti, ei työpanoksen lisääminen 7500 työtunnin jälkeen enää johda kovinkaan suureen tuntiansion nousuun. 


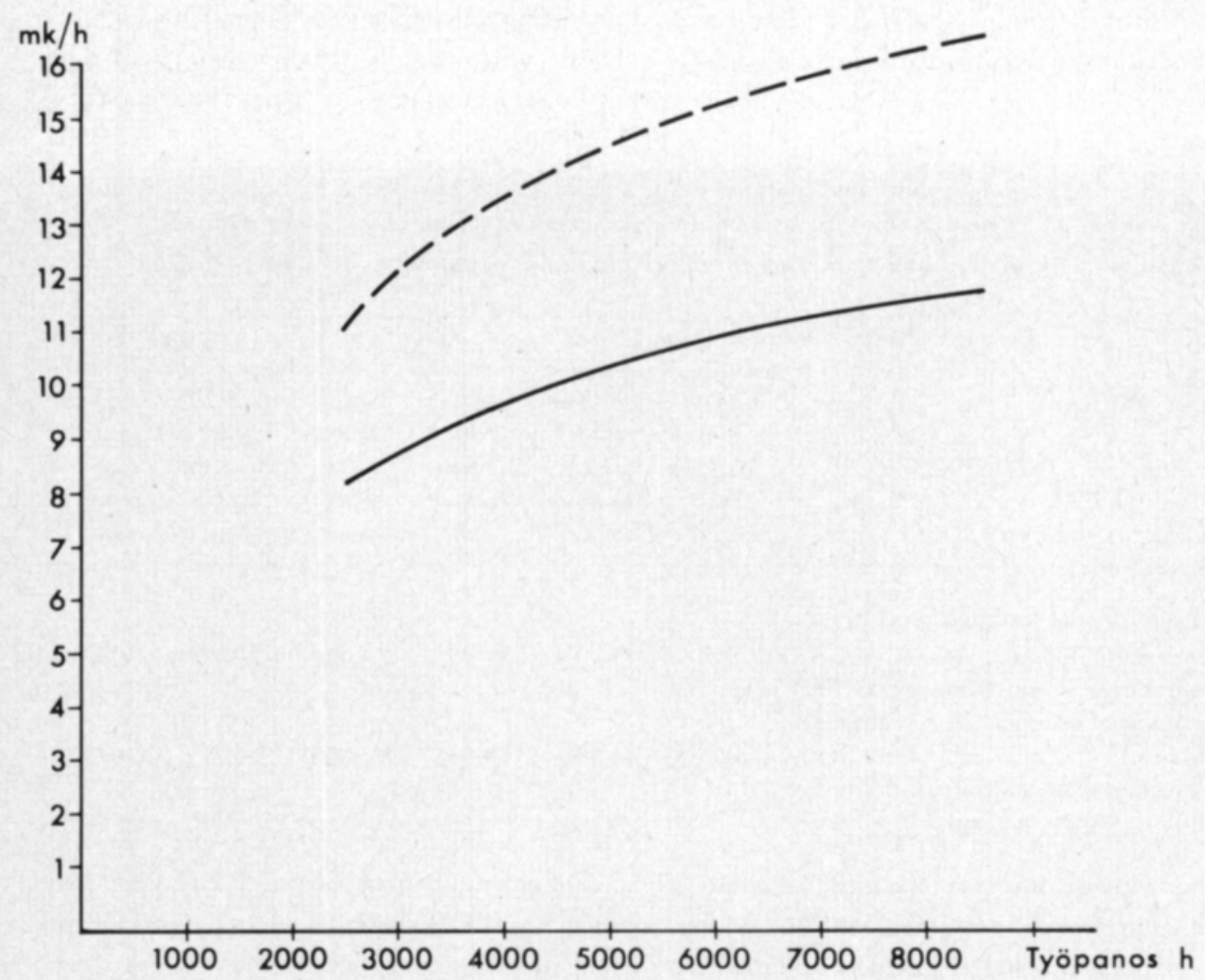

\section{- - - Korkea tekniikka \\ Keskikorkea tekniikka}

Kuvio 5 .

Fig. 5.

\subsection{Erikoistunut viljanviljely}

Maidontuotanto yhdistettynä karkearehun viljelyyn ja lypsylehmien uudistukseen osoittautui ratkaisujen yhteydessä parhaimmaksi tuotannonhaaraksi. Seuraava askel on tämän tuotannonhaaran poissulkeminen vaihtoehtoisten tuotannonhaarojen joukosta. Tällöin erikoistunut viljanviljely muodostuu seuraavaksi parhaimmaksi tuotantomuodoksi.

Taulukosta 9 ilmenee, että syysviljat ovat malleissa edullisemmassa asemassa kuin kevätviljat. Siksi kesantoala muodostuu verraten suureksi ja vaihtelee 20-30\%:n välillä kokonaispeltoalasta laskettuna. Rypsi voidaan malleissa kylvää yksinomaan kesantoon ja syysviljat joko rypsin tai kesannon jälkeen kaksi kertaa peräkkäin. Käytännössä viljelysuunnitelmat tehdään yleensä paljon staattisemmassa ympäristössä. Malleissa tehtävänä oli kombinoida peltoa ja pääomaa niin edullisesti kuin mahdollista tiettyihin etukäteen määrättyihin työpanoksiin. Tällä tavalla voidaan tutkia, mitkä ovat malleissa tapahtuvien rakennemuutosten liiketaloudelliset edellytykset. Syysviljojen etuna 
on vielä se, että varsinkin kevään työhuippu kasvinviljelyssä alenee. Peltopinta-alaltaan ovat esitetyt viljanviljelyyritykset varsin suuria. Korkeampi tuotantotekniikka johtaa luonnollisesti tilakoon kasvuun.

Taulukko 9. Tulosyhdistelmä. Viljanviljely-yritykset. Tuotannonhaarojen laajuudet eri teknisillä tasoilla ja työpanoksilla.

Table 9. Results of the calculations. Grain-producing farms. Sizes of fields of production at different technical levels and with different inputs of labour.

\begin{tabular}{|c|c|c|c|c|c|c|}
\hline \multirow{2}{*}{$\begin{array}{l}\text { Tuotannonhaara } \\
\text { Field of production }\end{array}$} & \multicolumn{2}{|c|}{$2500 \mathrm{~h}$} & \multicolumn{2}{|c|}{$5000 \mathrm{~h}$} & \multicolumn{2}{|c|}{$7500 \mathrm{~h}$} \\
\hline & $\begin{array}{c}\text { Keskik. } \\
\text { tekn. } \\
\text { Medium } \\
\text { techn. } \\
\text { level }\end{array}$ & $\begin{array}{c}\text { Korkea } \\
\text { tekn. } \\
\text { High } \\
\text { techn. } \\
\text { level }\end{array}$ & $\begin{array}{l}\text { Keskik. } \\
\text { tekn. } \\
\text { Medium } \\
\text { techn. } \\
\text { level }\end{array}$ & $\begin{array}{c}\text { Korkea } \\
\text { tekn. } \\
\text { High } \\
\text { techn. } \\
\text { level }\end{array}$ & $\begin{array}{l}\text { Keskik. } \\
\text { tekn. } \\
\text { Medium } \\
\text { techn. } \\
\text { level }\end{array}$ & $\begin{array}{c}\text { Korkea } \\
\text { tekn. } \\
\text { High } \\
\text { techn. } \\
\text { level }\end{array}$ \\
\hline $\begin{array}{l}\text { Kevätvehnä ha } \ldots \ldots \ldots \ldots \ldots \ldots \ldots . . . . . . . . . \\
\text { Spring wheat }\end{array}$ & 1 & 1 & & 49 & 48 & 58 \\
\hline $\begin{array}{l}\text { Rehuvilja ha } \quad \text { h....................... } \\
\text { Fodder crop }\end{array}$ & & & & 1 & & 26 \\
\hline 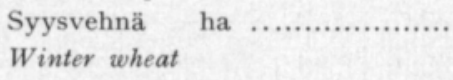 & 25 & 56 & 53 & 86 & 9 & 50 \\
\hline $\begin{array}{l}\text { Syysruis } \\
\text { Winter rye }\end{array}$ & & & & 1 & 51 & 76 \\
\hline 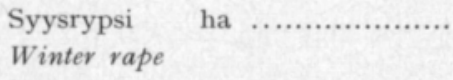 & 15 & & 28 & & 32 & \\
\hline 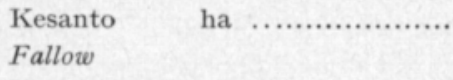 & 15 & 28 & 28 & 43.5 & 32 & 63 \\
\hline $\begin{array}{l}\text { Kokonaispinta-ala ha } . . . \ldots \ldots \ldots . . . . \\
\text { Total area }\end{array}$ & 56 & 85 & 109 & 180.5 & 172 & 273 \\
\hline
\end{tabular}

Taulukko 10. Viljanviljely-yritysten pääomantarve, $1000 \mathrm{mk}$.

Table 10. Need of capital on grain-producing farms, $1000 \mathrm{Fmk}$.

\begin{tabular}{|c|c|c|c|c|c|c|}
\hline & \multicolumn{2}{|c|}{$2500 \mathrm{~h}$} & \multicolumn{2}{|c|}{$5000 \mathrm{~h}$} & \multicolumn{2}{|c|}{$7500 \mathrm{~h}$} \\
\hline & $\begin{array}{l}\text { Keskik. } \\
\text { tekn. } \\
\text { Medium } \\
\text { techn. } \\
\text { level }\end{array}$ & $\begin{array}{l}\text { Korkea } \\
\text { tekn. } \\
\text { High } \\
\text { techn. } \\
\text { level }\end{array}$ & $\begin{array}{l}\text { Keskik. } \\
\text { tekn. } \\
\text { Medium } \\
\text { techn. } \\
\text { level }\end{array}$ & $\begin{array}{l}\text { Korkea } \\
\text { tekn. } \\
\text { High } \\
\text { techn. } \\
\text { level }\end{array}$ & $\begin{array}{l}\text { Keskik. } \\
\text { tekn. } \\
\text { Medium } \\
\text { techn. } \\
\text { level }\end{array}$ & $\begin{array}{l}\text { Korkea } \\
\text { tekn. } \\
\text { High } \\
\text { techn. } \\
\text { level }\end{array}$ \\
\hline $\begin{array}{l}\text { Koko pääomantarve ................. } \\
\text { Combined need of capital } \\
\text { Pääoman jakaantuminen } \\
\text { Distribution of capital }\end{array}$ & 551 & 797 & 1004 & 1603 & 1574 & 2365 \\
\hline $\begin{array}{l}\text { Rakennuspääoma ...................... } \\
\text { Capital for buildings }\end{array}$ & 104 & 139 & 187 & 302 & 305 & 452 \\
\hline $\begin{array}{l}\text { Konepääoma ................................. } \\
\text { Capital for machinery }\end{array}$ & 155 & 215 & 247 & 361 & 375 & 495 \\
\hline $\begin{array}{l}\text { Käyttöpääoma } \ldots \ldots \ldots \ldots \ldots \ldots \ldots \ldots . . . . . . . . . . . . . \\
\text { Operating capital }\end{array}$ & 13 & 19 & 25 & 38 & 34 & 53 \\
\hline $\begin{array}{l}\text { Peltopääoma } \\
\text { Capital for land }\end{array}$ & 280 & 425 & 545 & 903 & 860 & 1365 \\
\hline
\end{tabular}


Pääomantarve on viljantuotantoyrityksissä kauttaaltaan jonkin verran suurempi kuin maidontuotantoyrityksissä. Tämä johtuu etupäässä viljantuotantoyritysten suuresta peltoalasta, mutta myös konekanta sitoo näillä tiloilla runsaasti pääomaa. Käytännössä tulee jo riittävän yhtenäisten peltoalueiden harvalukuisuus - myöskin Etelä-Suomessa - rajoittamaan suurempien yritysten syntymistä. Työvoiman käyttö rajoittuu näissä vaihtoehdoissa kasvukauteen ja nimenomaan kevään ja syksyn työhuippuihin. Tällöin verraten suuri osa käytettävissä olevasta vuotuisesta työpanoksesta jää käyttämättä.

Taulukko 11. Viljanviljelytilojen työnkäyttō. Käyttämättä jääneet työtunnit eri vaihtoehdoissa.

Table 11. Labour requirement on grain-producing farms. Unused manhours in the different alternatives.

\begin{tabular}{|c|c|c|c|c|c|c|}
\hline & \multicolumn{2}{|c|}{$2500 \mathrm{~h}$} & \multicolumn{2}{|c|}{$5000 \mathrm{~h}$} & \multicolumn{2}{|c|}{$7500 \mathrm{~h}$} \\
\hline & $\begin{array}{c}\text { Keskik. } \\
\text { tekn. } \\
\text { Medium } \\
\text { techn. } \\
\text { level }\end{array}$ & $\begin{array}{c}\text { Korkea } \\
\text { tekn. } \\
\text { High } \\
\text { techn. } \\
\text { level }\end{array}$ & $\begin{array}{c}\text { Keskik. } \\
\text { tekn. } \\
\text { Medium } \\
\text { techn. } \\
\text { level }\end{array}$ & $\begin{array}{c}\text { Korkea } \\
\text { tekn. } \\
\text { High } \\
\text { techn. } \\
\text { level }\end{array}$ & $\begin{array}{c}\text { Keskik. } \\
\text { tekn. } \\
\text { Medium } \\
\text { techn. } \\
\text { level }\end{array}$ & $\begin{array}{c}\text { Korkea } \\
\text { tekn. } \\
\text { High } \\
\text { techn. } \\
\text { level }\end{array}$ \\
\hline Kevät - Spring .................... & 132 & 197 & 286 & 145 & 109 & 171 \\
\hline Syksy - Autumn ................... & 4 & 1 & 3 & 3 & 6 & 2 \\
\hline Koko vuosi - Entire year ....... & 1330 & 1533 & 2994 & 2735 & 4164 & 4082 \\
\hline
\end{tabular}

Täyden työllisyyden saavuttaminen on yksipuolisessa viljantuotannossa melko mahdotonta. Jäljelle jäänyt työaika voidaan käytännössä usein käyttää metsätalouteen tai sivuansioiden hankkimiseen.

Taulukko 12 osoittaa, että työansio erikostuneessa viljantuotannossa on varsin heikko - jopa negatiivinen joissakin vaihtoehdoissa. Varsinkin alem-

Taulukko 12. Työansio $\mathrm{mk} / \mathrm{t}$ ennen verotusta. Viljanviljely-yritykset.

Table 12. Yield per man-hour before taxes. Grain-producing farms.

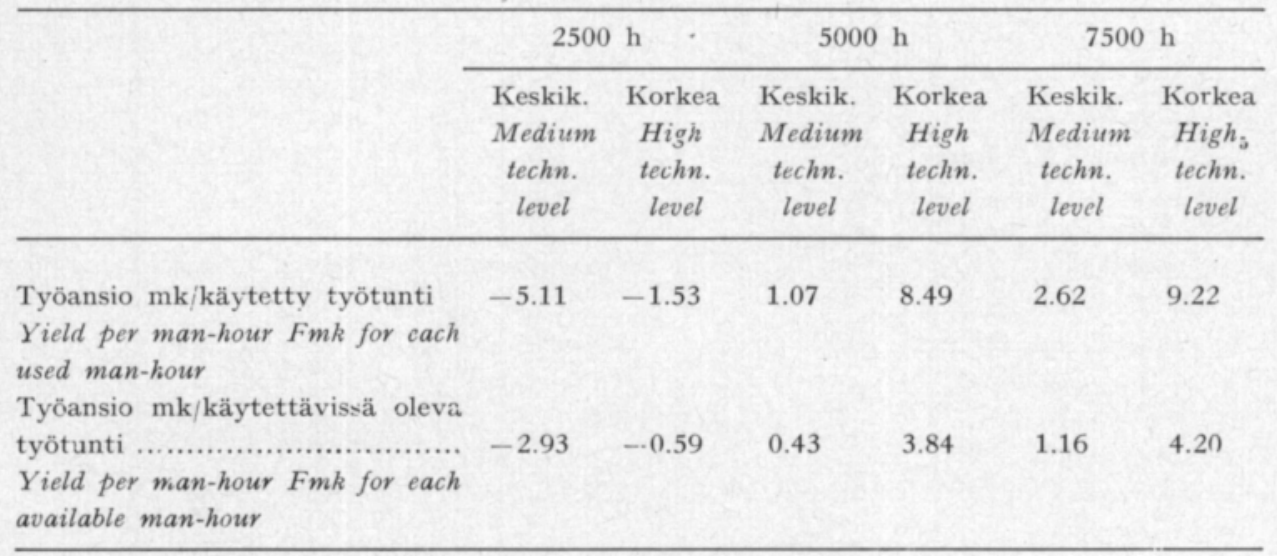


malla tuotantoteknisellä tasolla tilanne on heikko. Verrattuna maidontuotantoon on työansio ja samalla kannattavuus viljanviljelyssä mallien tuloksien mukaan selvästi alempi. Parannettu tuotantotekniikka ja suurempi työpanos korjuukauden aikana merkitsee kuitenkin työansion vähäistä paranemista, kuten kuvio 6 osoittaa.

Mallien mukaan ei näytä olevan kovin hyviä mahdollisuuksia tuntiansion lisäykseen nostamalla työpanosta. Saamieni tulosten perusteella tuntuu varsin epätodennäköiseltä, että viljantuotannon alalla voisi esitettyjen ehtojen vallitessa syntyä kuvatuntyyppisiä yrityksiä, kun otetaan huomioon nykyinen keskimääräinen tilakoko tutkimusalueella.

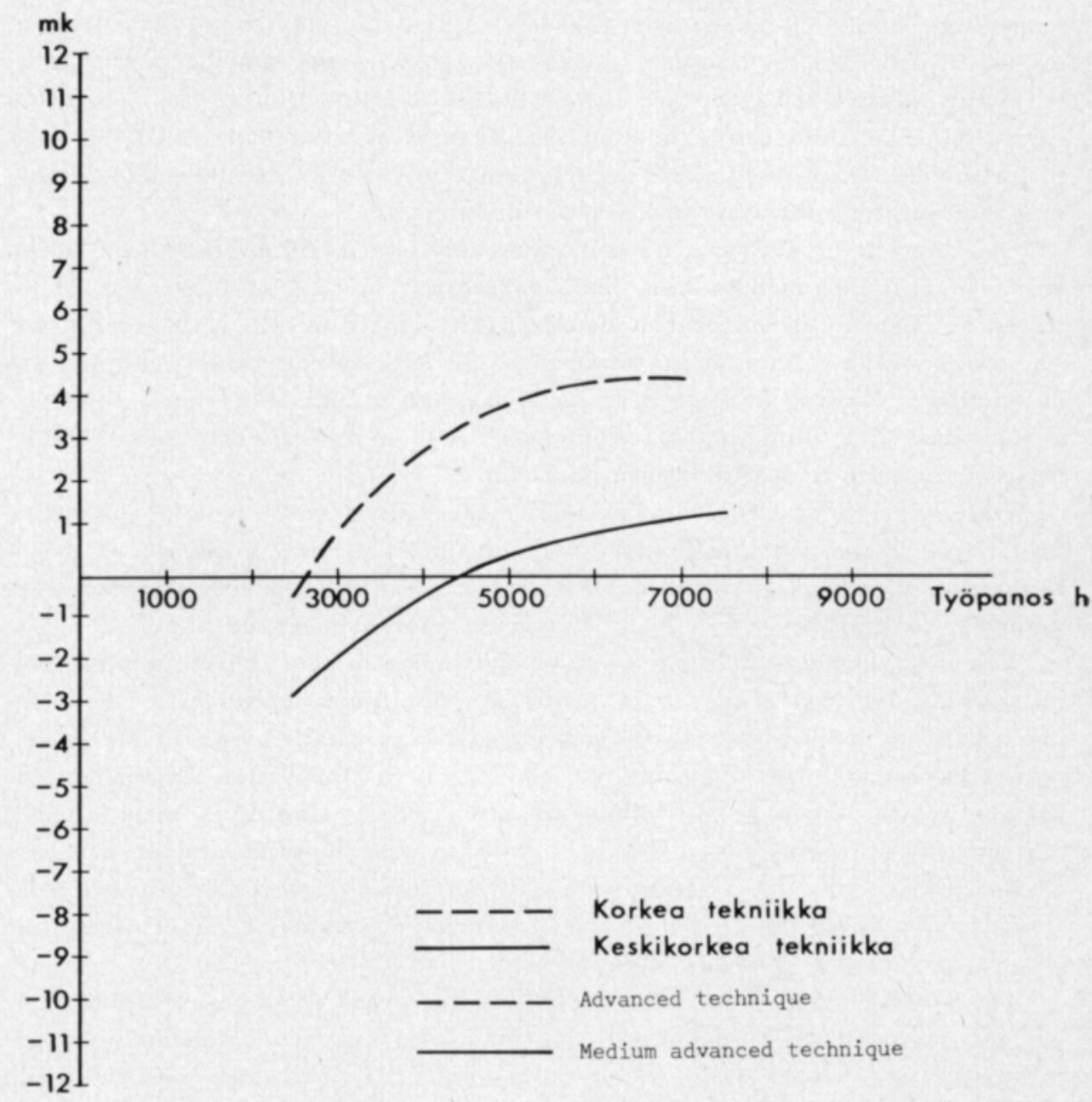

Kuvio 6.

Fig. 6. 


\section{Maatalousyritysten kasvuongelmat}

Tässä tutkimuksessa pyritään selvittämään maatalouden rakennerationalisoinnin liiketaloudellisia edellytyksiä. Aluksi on mallien avulla tutkittu, miten työansio kehittyy samaa tuotantotekniikkaa sovellettaessa ja tuotantovolyymin jatkuvasti kasvaessa. Tämän lisäksi on kahta tuotantoteknistä tasoa verrattu keskenään. Tarkastelu on kuitenkin ollut tavallaan staattista. On toisin sanoen laskettu, minkälaiseksi työansio muodostuu erisuuruisilla tiloilla, kun tuotantotekniikka on jatkuvasti samanlainen.

Olen pyrkinyt ottamaan huomioon malleissa ne laajuusvaikutukset, jotka kohdistuvat panospuolella mm. työn tarpeeseen ja pääomankäyttöön. Tuotosten suhteen ei ole voitu arvioida ilmeisesti olemassaolevia laajuusvaikutuksia, vaikka niiden huomioonottaminen olisi ollut mallien rakenteen puolesta mahdollista. Malliratkaisujen perusteella voidaan tämän takia saada vain karkea käsitys siitä, minkälaiseksi työn korvaus ja myös kannattavuus muodostuisivat tuotannon laajuuden vaihdellessa.

Tilannetta on tarkasteltu sellaisena, että malliyritykset jo ovat saavuttaneet tietyn koon. Perinteellisellä tavalla on tällöin pyritty optimoimaan tietyn rajoitetun panosmäärän käyttöä. Lisäämällä panosmäärää asteittain on kasvuongelmaa käsitelty vertailevan staattisen analyysin avulla.

Yritykset lienevät kuitenkin varsin epästaattisia. On melko helppoa empiirisestikin osoittaa etuja, jotka johtuvat tuotannon laajuudesta. Kun samanaikaisesti on olemassa vastakkaiseen suuntaan vaikuttavia voimia, on yritysten kasvuongelmaa aikaisemmin pohdittaessa usein pyritty löytämään yrityksen optimaalinen koko. Tämä on kuitenkin osoittautunut melko hedelmättömäksi lähtökohdaksi. Mitään ehdotonta tasapainotilaa tässä suhteessa ei ole löydetty. Penrose (1968) toteaakin, että yritykset, joilla on tarkoituksenmukainen liikkeenjohto, pyrkivät jatkuvasti kasvamaan, ja että kasvulle ei käytännöllisesti katsoen voida asettaa rajaa.

Tässä tutkimuksessa on vain osittain voitu ottaa huomioon tekijöitä, jotka edistävät yrityksen kasvua. Se johtuu osaksi kyseisen aineiston puutteellisuudesta. Penrosen (1968) hypoteesien mukaan ei ainoastaan yrityksen koko vaan myöskin kasvutapahtumat sinänsä voivat tarjota yrityksille taloudellisia etuja. Tämä pätee Penrosen mukaan riippumatta siitä vaiheesta, missä yritys suuruuskehityksessä kulloinkin on. Viimeksi mainittuja etuja ei kuitenkaan toistaiseksi ole voitu kvantifioida.

Myös eräät muut kasvua koskevat teoriat eivät edellytä yritysten optimikokoa. MArshall (1922) ja myöhemmin Boulding (1950) ovat esittäneet metsän puut yritysten biologisena analogiana. Keskeisin ajatus tässä on, että yri- 
tykset kamppailevat toisten yritysten kanssa elintilasta ja että jotkin yritykset saavat haltuunsa enemmän kasvua aiheuttavia tekijöitä kuin muut. Ajan mittaan yritykset kuitenkin menettävät elinvoimansa ja lopulta kuolevat. Nämä hypoteesit ovat myöskin jääneet empiirisesti todistamatta. Maatilatalouden olosuhteet eivät ainakaan kokonaisuudessaan näytä tukevan tällaista teoriaa. Voidaan kuitenkin verraten helposti osoittaa, että yrityksiä kuolee. Uusien yritysten syntyminen lienee sitävastoin harvinaista. Väistyvien yritysten tuotantopanokset liitetään useimmiten jo olemassaoleviin yrityksiin. Olettamus kaikkien yritysten väistämättömästä kuolemasta tuntuu kuitenkin epäonnistuneelta.

Edellä selostetun perusteella voidaan olettaa, että maatalousyritykset voisivat jatkuvasti kasvaa ainakin mikäli otetaan huomioon ne yrityslaajuudet, mitkä ovat tulleet esille malliratkaisujen yhteydessä. Olettamus ei tietenkään tarkoita sitä, että tämä koskisi käytännössä jokaista maatalousyritystä. On luonnollisesti olemassa myös sellaisia yrityksiä, jotka jostakin syystä eivät kasva. Tämä staattinen tai suhteellisesti ottaen regressiivinen osa on maataloudessa ilmeisesti ollut ja on edelleen suhteellisen suuri. Tässä tutkimuksessa ei ole kosketeltu tämän osa-alueen ongelmia.

Tutkimuksessa käytetty vertaileva staattinen tarkastelutapa ei sinänsä kiellä jatkuvan kasvun mahdollisuutta, mutta kasvu tapahtuu sen mukaan vain tietyin väliajoin. Kasvun aikana siirrytään toiselta laajuusasteelta toiselle ja siirtymisien välillä on staattisia kausia; kasvu ikäänkuin pysähtyy väliaikaisesti. Tämä olettamus ei tunnu kovin realistiselta varsinkin jos tarkastellaan eri alojen yritysten käyttäytymistä. Paljon mielekkäämmältä vaikuttaa sellainen olettamus, että yritysten laajuus muuttuu keskeytyksittä, mutta muuttumisen nopeus voi vaihdella.

Staattinen tai vertaileva staattinen tarkastelutapa näyttää edellä selostetun perusteella hieman epäonnistuneelta. Voidaankin todeta, että nykyään sekä tutkimuksessa että käytännön suunnittelussa käytettävissä olevat menetelmät ovat luonteeltaan liian staattisia. Tietomme maatalousyritysten kasvuprosessista yleensä ovat kuitenkin suhteellisen rajalliset. Käyttökelpoisten suunnittelumenetelmien kehittäminen on osaksi tämän takia ollut vaikeata. Tässä työssä onkin ollut pakko tyytyä vertailevaan staattiseen tarkastelutapaan. Ehdotettujen suhteellisen suurten investointien jälkeen maatalousyrityksen toiminta todennäköisesti jatkuu jonkin aikaa miltei muuttumattomana. Tällä tavalla vertailevaa staattista tarkastelutapaa, johon liitetään ns. ylimenokauden laskelmat, voidaan osittain puolustaa.

Yritysten kasvua edistäviä tekijöitä on siis verraten paljon ja ne ovat helposti osoitettavissa. Yhtä ilmeistä on, että esiintyy myös tekijöitä, jotka vaikuttavat vastakkaiseen suuntaan. On voitettava useita vaikeuksia, ennen kuin voidaan kehittää yritystä haluttuun suuntaan. Se seikka, että rakennemuutokset maatilataloudessa tähän saakka ovat olleet hitaita osoittaa, että kasvuun liittyvät vaikeudet useimmissa tapauksissa ovat painaneet enemmän kuin vastaavat edut. PENRose (1968) mainitsee, että vakavin este itse yrityksessä on yleensä tarvittavien liikkeenjohtokyvyn sekä teknisen taidon puute. Yrittäjä ei toisin sanoen pysty tehokkaasti suunnittelemaan ja toteuttamaan uutta tuotanto-ohjelmaa. Tähän aspektiin ei ole kuitenkaan tämän tutkimuksen yhtey- 
dessä mahdollista kajota. Olen tyytynyt asettamaan rajoituksia yrityksen kasvulle määrittämällä korkeimman mahdollisen lainapääoman suhteessa omaan pääomaan.

Myöskin heikko maksuvalmius voi hidastaa kasvua ja käytännössä ehkä jo etukäteen lamaannuttaa yrittäjän toimintaa. Tämä vaikeus johtuu siitä, ettei useinkaan voida välittömästi ottaa käyttöön investoinneilla luotua tuotantokapasiteetin lisäystä. Esimerkiksi tarkoituksenmukaisen kasvinviljelyjärjestelmän kehittäminen tai rakennuskapasiteetin lisääminen vie aikaa.

Pääoman kiertonopeus on maataloudessa pieni. LiNDBERG (1970) on mitannut tämän nopeuden ja saanut suhdeluvuksi maataloudessa 0.40 , kun vastaava luku koko teollisuudessa on 1.11. Teollisuudessa kiertonopeus olisi tämän mukaan kolme kertaa suurempi kuin maataloudessa. Lindberg toteaakin, että maatalousyritysten on paljon vaikeampaa maksaa takaisin saamiaan luottoja kuin muiden yritysten ja että velkaprosentti (velkapääoma/koko pääoma) tämän takia on pysynyt alhaisena: vuonna 1968 se oli noin $14.4 \%$. Velkapääoman osuus on kuitenkin jonkin verran kasvanut varsinkin 60-luvulla ja on hyvin todennäköistä, että kehitys on jatkunut samaan suuntaan myös 70-luvulla. On huomattava, että pääoman kiertonopeus kasvavissa maatalousyrityksissä voi olla suurempi kuin edellä mainittu keskiarvo.

IнAмUотіLA (1971) on ennustanut, että maatalouden velat olisivat 70-luvun keskivaiheilla noin $17 \%$ varoista. On otettava huomioon, että inflaation on ennusteessa oletettu jatkuvan ainoastaan $4 \%$ :n vuosivauhdilla. Myöskin on muistettava, että mainitut luvut ovat keskiarvoja. Merkittävästi kasvaneita yrityksiä oli 60-luvun lopussa ja 70-luvun alussa ilmeisesti suhteellisen vähän. Nähdäkseni lainapääoman osuus tulee todennäköisesti olemaan kasvavissa yrityksissä ratkaisevasti suurempi.

Käytännössä pääoman hidas kiertonopeus siis helposti johtaa maksuvaikeuksiin, jotka heikon kannattavuuden ohella johtuvat lähinnä lainojen ja ko. investointikohteiden erilaisista kestoajoista. Maatalouden erikoispiirre on tässä suhteessa pellon arvion säilyminen. Mutta myös tuotantorakennusten ja osaksi koneidenkin kestoaika on pitempi kuin kyseisten lainojen poistoajat. Maatataloudessa joudutaan siis etukäteen arvioiden verraten helposti maksuvaikeuksiin, mikäli lainapääoman osuus muodostuu suureksi.

Tässä yhteydessä en ole tutkinut metsätulojen vaikutusta maksuvalmiuteen. Suomessahan maatilatalous tyypillisesti muodostuu sekä maa- että metsätaloudesta. Metsästä saatuja tuloja on todennäköisesti usein käytetty hyväksi maksuongelmien ratkaisussa. Tämä seikka voi käytännössä vaikuttaa pienentävästi lainapääoman tarpeeseen ja samalla positiivisesti koko maksuvalmiuteen.

Seuraavassa olen pyrkinyt selvittämään yritysten investoinneista johtuvia maksuvalmiusongelmia. Tällöin on erikoisesti kiinnitettävä huomiota kah teen seikkaan: investointien rahoitukseen ja niiden ajoitukseen.

\subsection{Yrityksen rahoitus}

Kuten aikaisemmin on selvinnyt, tutkimuksen laskelmat eivät liity todellisiin yrityksiin, vaan edelleen työskennellään aikaisempien yritysmallien avulla, jotka kuitenkin on sijoitettu toimimaan sellaisessa ympäristössä, joka ominai- 
naisuuksiltaan vastaa tutkimusalueen ominaisuuksia. Yritysmalleissa ei ole rajoitettu pääoman saantia. Eri tarkoituksia varten on kuitenkin oletettu myönnetyksi yleisen käytännön mukaan erilaisia lainoja. Seuraavasta asetelmasta ilmenevät lainojen ehdot.

$\begin{array}{lc}\text { Lainan kohde } & \text { Takaisinmaksuaika, } \mathrm{v} \text { Korkoprosentti } \\ \text { Purpose of loan } & \text { Time for which loan Interest rate } \\ & \text { is granted, years }\end{array}$

Lisẵpellon hankinta - Field

Konehankinta - Machinery .......................

Rake:inusten laajentaminen - Buildings ......

Eläinten bankinta - Animals.

Käyttövarojen hankinta - Operating capilal

$\begin{array}{rr}10 & 6 \\ 5 & 8 \\ 10 & 8 \\ 5 & 8 \\ 5 & 8\end{array}$

Pellon osalta korkokanta on ainoastaan $6 \%$. Tällä tavalla on yritetty ottaa jossakin määrin huomioon valtion toimenpiteet rakennerationalisoinnin helpottamiseksi.

Yleisessä keskustelussa viitataan usein pääomansaannin vaikeuteen ja sen maatalousyrityksen kasvua rajoittaviin vaikutuksiin. PENRose (1968) toteaa kuitenkin, että pääoman saanti riippuu ratkaisevasti myöskin yrittäjän henkilökohtaisista ominaisuuksista. Vaikka toinen yrittäjä epäonnistuu, voi toinen yrittäjä samassa tilanteessa helposti saada tarvitsemansa lainan. Tutkimuksessa on oletettu, että yrittäjällä on tarpeelliset tiedot ja taidot.

\subsection{Oman pääoman osuus}

Aikaisemmin jo huomautin, että laskelmat eivät koske olemassaolevia yksittäisiä yrityksiä. 2500 työtunnin vaihtoehdoissa olen tosin ottanut lähtökohdaksi pysyviä peltoja viljelevien tilojen keskimääräisen peltoalan tutkimusalueella, mutta muuten oman pääoman osuudet määräytyvät seuraavan taulukon mukaisesti.

Taulukko 13. Oman pääoman osuus koko pääomasta eri teknisillä tasoilla ja erisuuı uisilla työpanoksilla.

Table 13. The proportion of farmer's own capital in total capital at different technical levels and with different inputs of labour.

\begin{tabular}{|c|c|c|c|c|c|c|}
\hline \multirow[t]{2}{*}{$\begin{array}{l}\text { Päảomalaji } \\
\text { Cutegory of } \\
\text { capital }\end{array}$} & \multicolumn{3}{|c|}{$\begin{array}{c}\text { Keskikorkea tuotantotekniikka } \\
\text { Medium advanced production } \\
\text { technique }\end{array}$} & \multicolumn{3}{|c|}{$\begin{array}{c}\text { Korkea tuotantotekniikka } \\
\text { Advanced production } \\
\text { technique }\end{array}$} \\
\hline & $2500 \mathrm{~h}$ & $5000 \mathrm{~h}$ & $7500 \mathrm{~h}$ & $2500 \mathrm{~h}$ & $5000 \mathrm{~h}$ & $7500 \mathrm{~h}$ \\
\hline Pelto - Field ................ & $100000 \mathrm{mk}$ & $50 \%$ & $50 \%$ & $100000 \mathrm{mk}$ & $50 \%$ & $50 \%$ \\
\hline Koncet - Machinery ...... & $35 \%$ & $35 \%$ & $35 \%$ & $15 \%$ & $15 \%$ & $15 \%$ \\
\hline $\begin{array}{l}\text { Rakennukset }- \text { Buildings } \\
\text { Eläinpääona }- \text { Capital }\end{array}$ & $35 \%$ & $35 \%$ & $35 \%$ & $15 \%$ & $15 \%$ & $15 \%$ \\
\hline $\begin{array}{l}\text { for animals } \\
\text { Käyttöpääoma - Operat }\end{array}$ & $50 \%$ & $50 \%$ & $50 \%$ & $50 \%$ & $50 \%$ & $50 \%$ \\
\hline ing capital ........................ & $0 \%$ & $0 \%$ & $0 \%$ & $0 \%$ & $0 \%$ & $0 \%$; \\
\hline
\end{tabular}




\section{Maksuvalmiusvaranto}

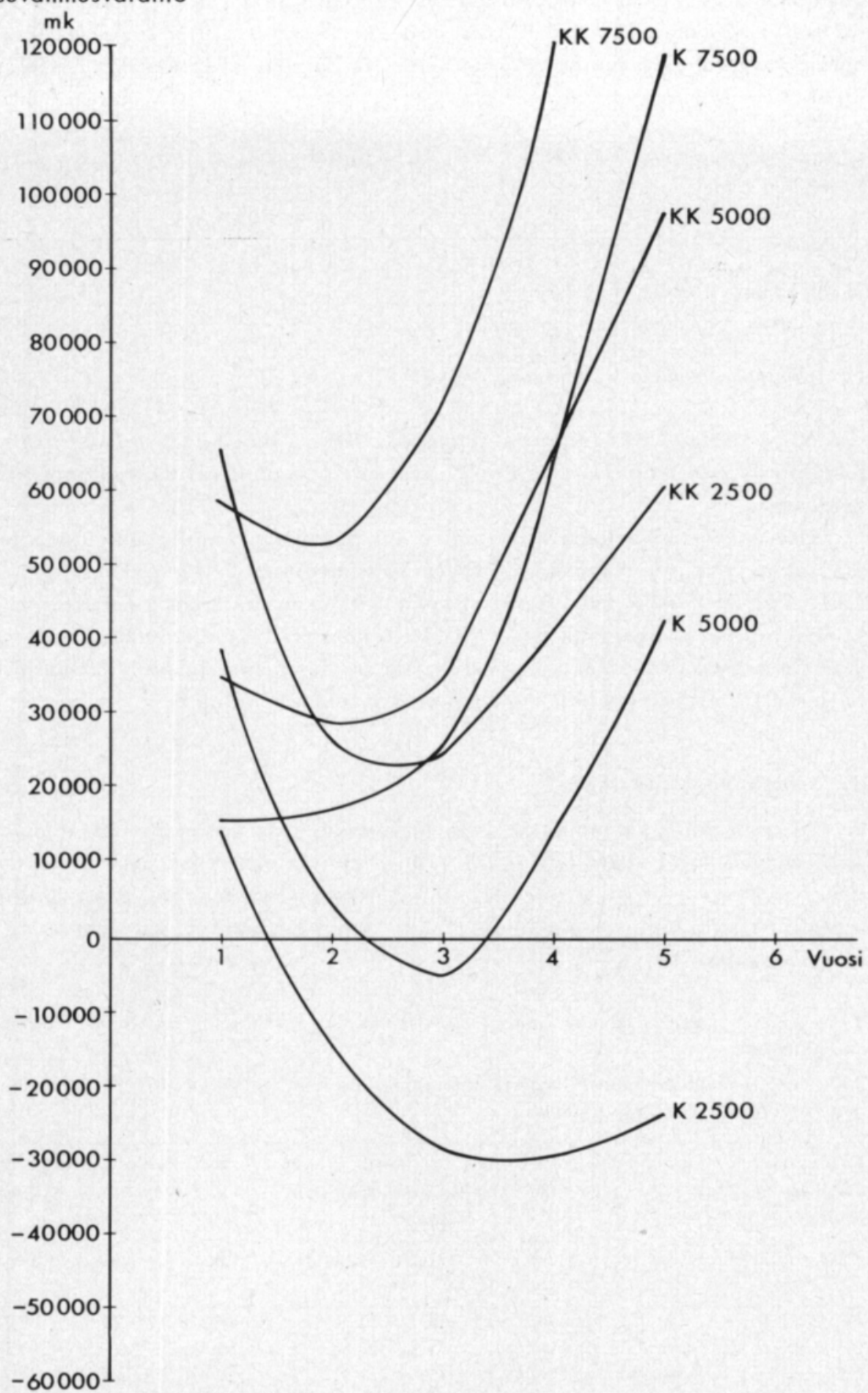

Kuvio 7. Vaihtoehtoisten tilamallien kumulatiivinen maksuvalmiusvaranto siirtymäkauden aikana. Maidontuotantoyritykset. Vaihtoehto I.

Fig. 7. The cumulative balance at end of year of alternative types of farms during period of transition. Milk producing farms. Alternative $I$. 
Lähtökohtana on velaton yritys, jolla ei ole säästöjä investointeja varten. Toisaalta on otaksuttu, että yrittäjä voi teknisesti kasvattaa tilaansa korkeintaan niin, että uusi tila pinta-alaltaan ja/tai lehmämäärältään on kaksi kertaa suurempi kuin entinen (vrt. pääomarajoitus). Yrityksen kasvattaminen vaatii sekä teknistä että taloudellista tietoa. Todella merkittävät laajennukset vaativat viljelijältä huomattavan paljon yrittäjänkykyä. Osittain tämän takia on yrityksellä asetettu taulukossa 13 esiintyvät rajoitukset.

\subsection{Investointien ajoitus}

Yleisenä periaatteena on luonnollisesti ollut, että lisääntynyt tuotantokapasiteetti tulisi täydellä teholla ottaa käyttöön niin pian kuin mahdollista. On kuitenkin teknisesti mahdotonta suorittaa välittömästi kaikki tarvittavat muutokset. Rajoittavia tekijöitä on maatilataloudessa useita. Esimerkiksi riittävän laajan rehukasvien viljelyn aloittaminen tai rakennushankkeen toteuttaminen vie aikaa. Siirtymäkauden pituus vaihtelee käytännössä monestakin syystä. Laskelmissa on otaksuttu, että rakennerationalisointi ei vaikuta yrityksen tuotantomuotoon, mikä luonnollisesti vähentää siirtymäkauden vaikeuksia. Laskelmissa on pyritty myös minimoimaan siirtymäkauden pituutta. Tässä mielessä on oletettu, että maidontuoțannossa uusi kapasiteetti otetaan välittömästi käyttöön ostamalla lehmiä tai kantavia hiehoja ja että uuden kasvijärjestyksen kunnostus vie yhden vuoden. Rakennuskapasiteetin lisääminen vie malleissa myös korkeintaan yhden vuoden. 


\section{Investointilaskelmien tulokset}

Laskelmat on tehty käyttämällä Maatalouden laskentakeskuksen INLAjärjestelmää. Tämä tietokonekäsittelyyn pohjautuva järjestelmä on varsin monipuolinen, mutta siinä on kuitenkin annettu suuri paino maksuvalmiuden seuraamiselle (HAKola 1974, TTK Maatalouden suunnittelu, moniste).

Malliyritysten rahavirtoja on laskelmissa seurattu viiden vuoden ajan.

Tässä työssä on seurattu niitä ehtoja, joita investointien ajoituksen ja rahoituksen suhteen on asetettu. Rahavirtojen kulkua on siis tutkittu simulointimenettelyn avulla. Maksuvalmiuslaskelmien tuloksista ilmenee siirtymäkauden eri vuosien kumulatiivinen loppusaldo, joka yleensä voidaan käsittää yrityksen maksuvalmiusvarannoksi. Nyt puheena olevien laskelmien yhteydessä tilanne on kuitenkin hiukan erilainen. Koska työkustannuksia ei ole otettu huomioon, pitäisi vuoden loppusaldon eli maksuvalmiusvarannon tässä tapauksessa riittää sekä viljelijäperheen toimeentuloon että maksuvalmiuden turvaamiseen. Alempana esitetään maksuvalmiuslaskelmien tulokset graafisesti.

\subsection{Maidontuotantoyritykset}

Kuviosta 7 ilmenee, että korkean tuotantotekniikan mallissa maksuvalmius on erittäin heikko. Tuotostason korkeus on yleensä siirtymäkauden aikana melko epävarma. Pelkästään tämä tekijä voi aiheuttaa suhteellisen suuria vaihteluja tulopuolella ja saattaa maksuvalmiuden vaaraan. Paras vaihtoehto maksuvalmiuden osalta on se, jossa muutokset ovat pienimmät.

Hyvin heikkoja maksuvalmiudeltaan ovat mallit K 2500 ja K 5000. Yleinen johtopäätös laskelmien perusteella on, että siirtymäkauden maksuvalmiuden heikkous voi hyvin helposti johtaa kriittiseen tilanteeseen yrityksen selviytymisen kannalta. Ilmeisesti mikään malliyritys ei selviäisi ilman apua, kun otetaan huomioon viljelijäperheen toimeentulo.

Muuttamalla oman pääoman suhdetta vieraaseen pääomaan on seuraavassa tutkittu, miten maksuvalmius paranee. Taulukossa 13 edellytettiin, että lähtökohtayrityksellä on puolet tulevasta peltoalasta. Tätä ehtoa tiukennetaan nyt siten, että yrityksellä pitää olla koko tarvittava peltoala. Muiden panosten kohdalla säilyy pääomasuhde ennallaan.

Kuvio 8 osoittaa, että malliyritysten maksuvalmius on parantunut huomattavasti. Vieraan pääoman osuuden väheneminen on vaihtoehtojen välillä 1415 prosenttiyksikköä, paitsi 2500 työtunnin malleissa, joissa vähennys on pienempi. Ainoastaan malli K 2500 on nyt maksuvalmiudeltaan täysin ala-arvoinen. Muut mallit tuntuvat jo tässä vaiheessa melko vakailta. Vieraan pää- 
oman osuus on luonnollisesti suurempi korkeammalla teknisellä tasolla. Ero tutkittujen teknisten tasojen välillä on taulukko 9:n mukaan yli 10 prosenttiyksikköä. Tästä syystä rahoituksen alkuvaikeudet ovat suurempia korkeammalle tekniselle tasolle siirryttäessä. Toisen vaihtoehdon mallit K 7500 ja

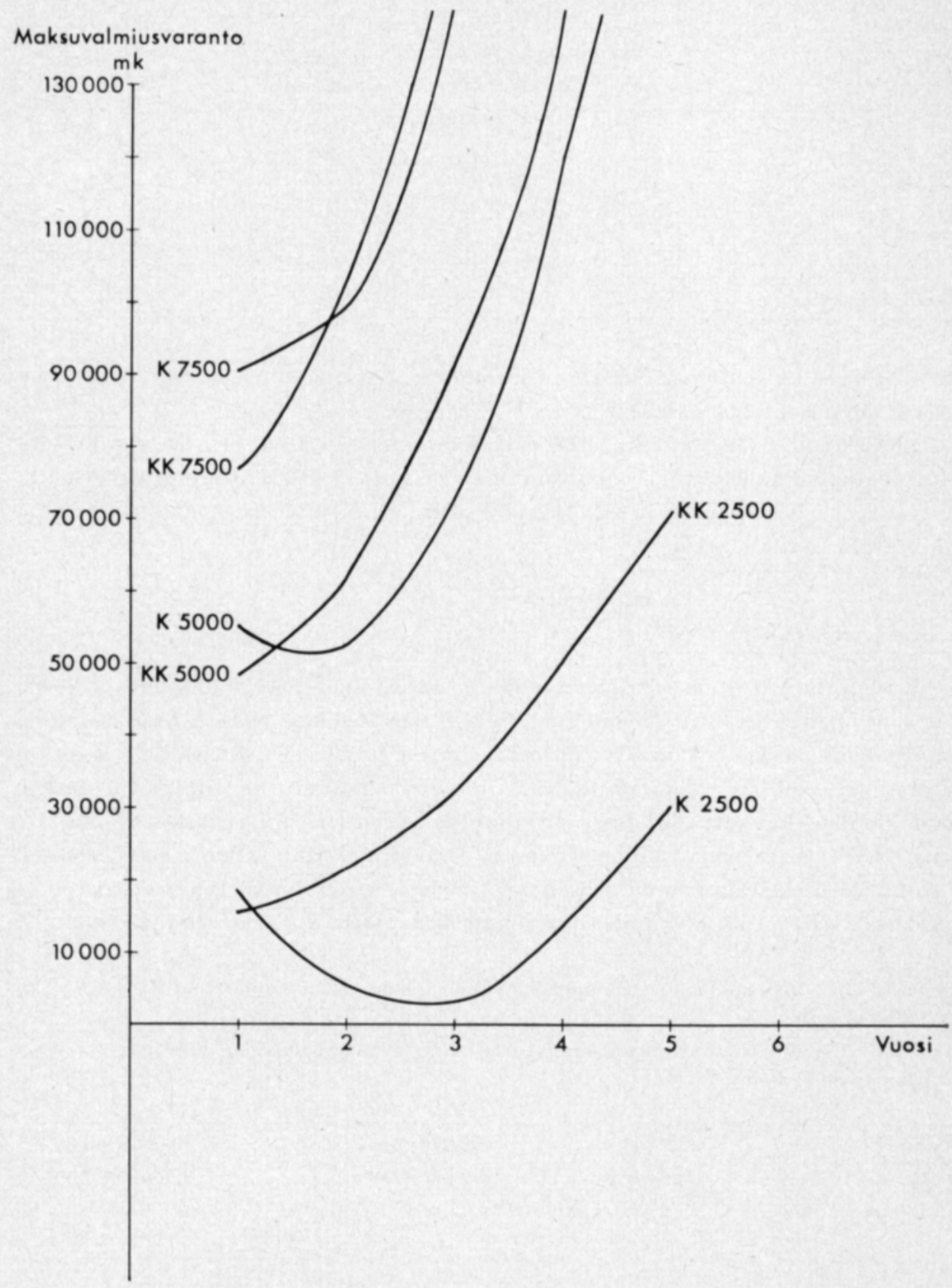

Kuvio 8. Vaihtoehtoisten tilamallien kumulatiivinen maksuvalmiusvaranto siirtymäkauden aikana. Maidontuotantoyritykset. Vaihtoehto II.

Fig. 8. The cumulative balance at end of year alternative types of farms during period of transition. Milkproducing farms._Alternative II. 
Taulukko 14. Vieraan pääoman suhteellinen osuus koko pääomasta maidontuotantoyritysten eri vaihtoehdoissa.

Table 17. The proportion of loaned capital relative to the total capital in different alternatives of milk-producing farms.

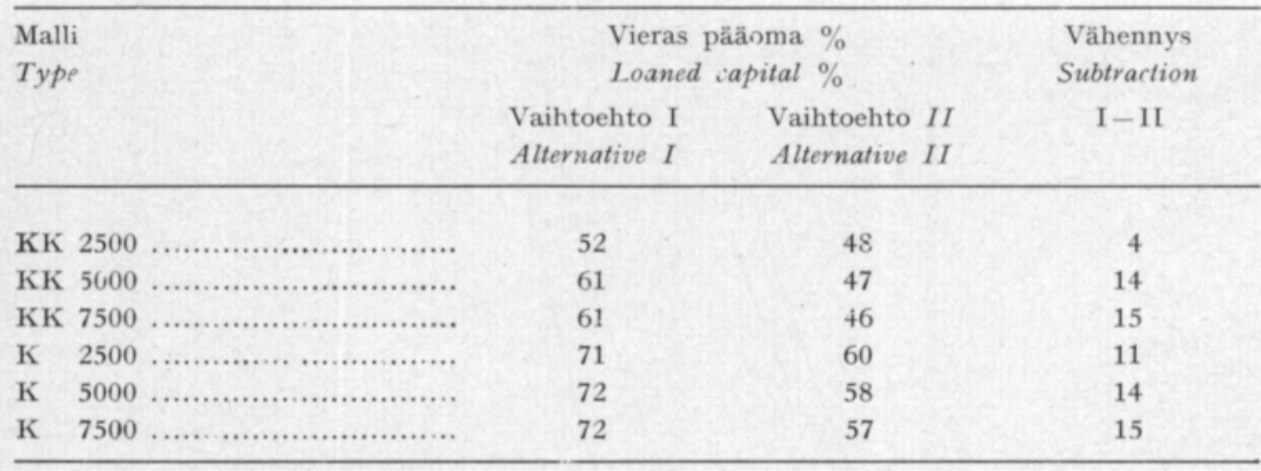

K 5000 ovat kuitenkin jo viiden ensimmäisen vuoden kuluttua ohittaneet vastaavat alemman tason mallit.

Yleisesti voidaan havaita, että maksuvalmius tuntuu kestävän maidontuotantomalleissa noin $50 \%$ :n lainaosuuteen saakka varsinkin suuremmissa malliyrityksissä. Edellytyksenä on luonnollisesti, että rahoitus voidaan järjestää ehdotetulla tavalla.

\subsection{Viljanviljely-yritykset}

Kuvioihin 9 ja 10 ei ole otettu mukaan niitä viljanviljelyvaihtoehtoja, jotka antoivat kannattavuuslaskennassa negatiivisen työkorvauksen, koska nämä vaihtoehdot eivät ole mielenkiintoisia maksuvalmiuden kannalta. Myöskin viljanviljelyvaihtoehtojen yhteydessä on maksuvalmiutta suhteessa omaan pääomaan tarkastettu kahdessa eri tilanteessa, jotka selviävät taulukosta 15 . Laskelmien perusteella voidaan todeta, että viimeistään silloin, kun vieraan pääoman osuus koko pääomasta nousee yli $50 \%$, malliyritysten maksuvalmius romahtaa. Tämä koskee molempia teknisiä tasoja ja kaikkia yrityskokoja.

Taulukko 15. Vieraan pääoman suhteellinen osuus koko päkiomasta viljanviljely-yritysten eri vaihtoehdoissa.

Table 15. The proportion of loaned capital relative to the total capital in different alternatives of grain-producing farms.

\begin{tabular}{lccc}
\hline Malli & Vieras pääoma $\%$ & Vähennys \\
Type & Loaned capital $\%$ & Subtraction \\
& Vaihtoehto I & Vaihtoehto II & I-II \\
& Alternative I & Alternative II & \\
\hline
\end{tabular}

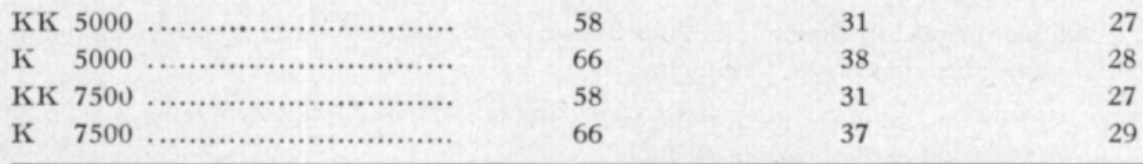




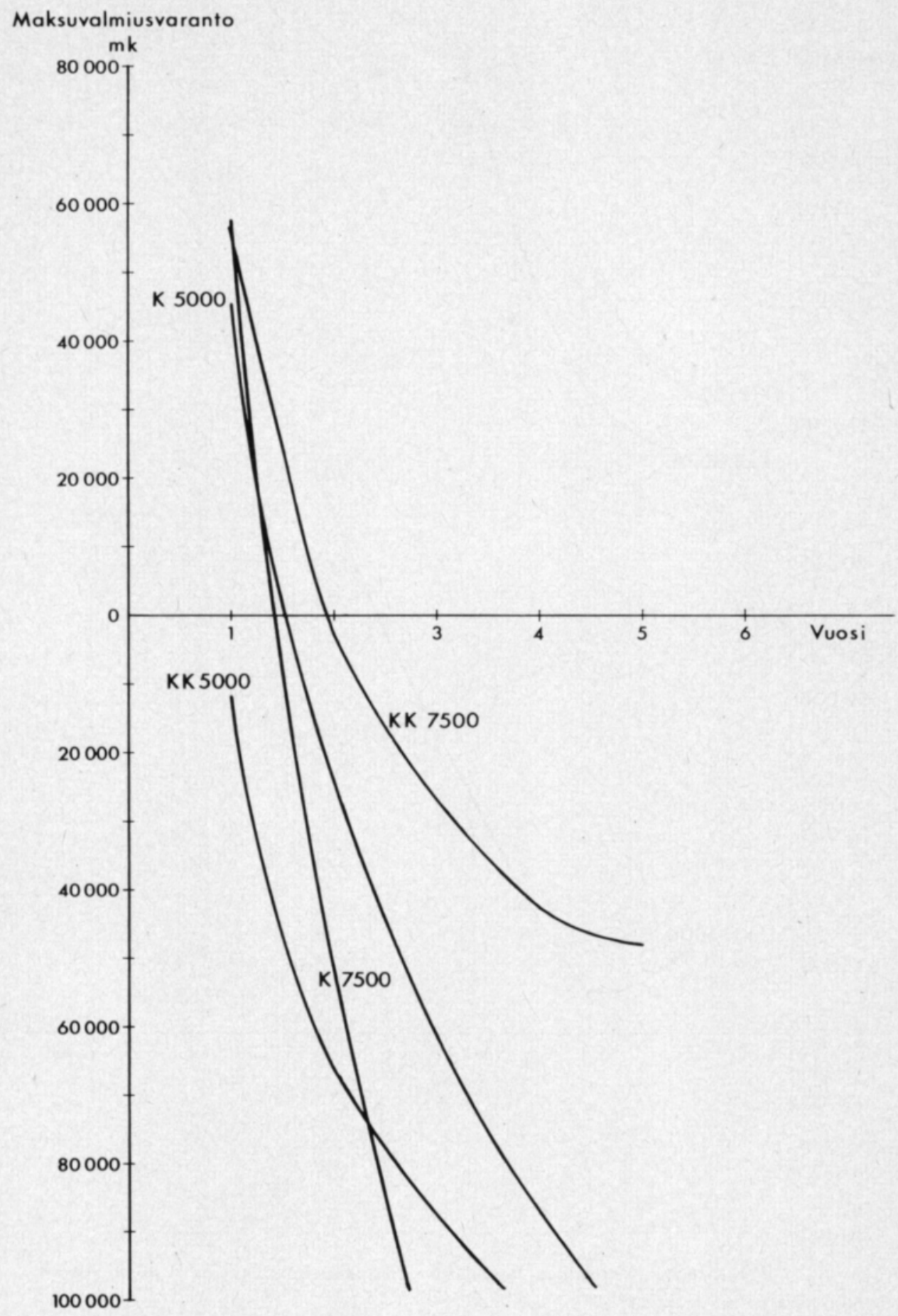

Kuvio 9. Vaihtoehtoisten tilamallien kumulatiivinen maksuvalmiusvaranto siirtymäkauden aikana. Viljanviljely-yritykset. Vaihtoehto I.

Fig. 9. The cumulative balance at end of year of alternative types of farms during period of transition. Grain-producing farms. Alternative $I$. 


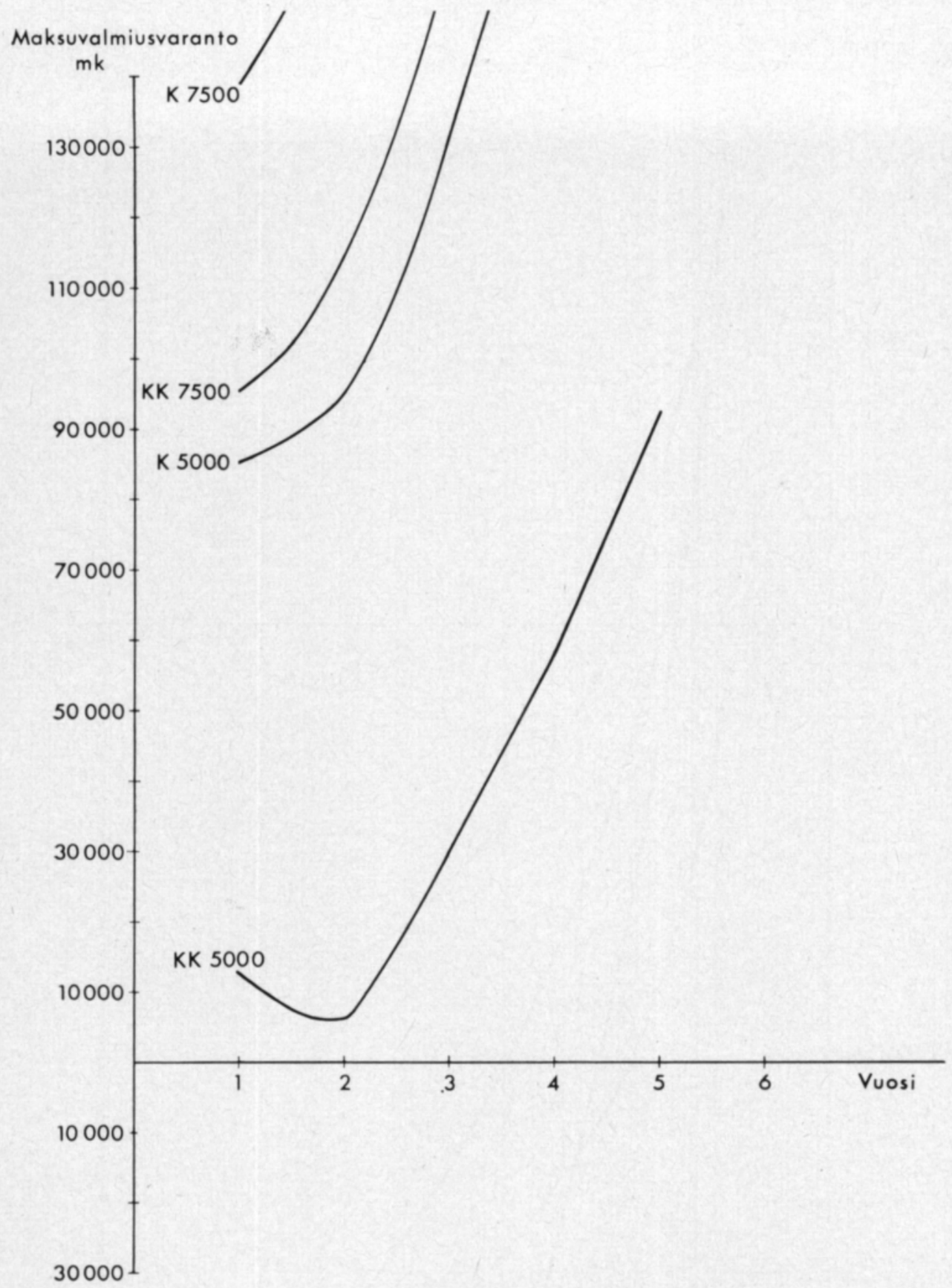

Kuvio 10. Vaihtoehtoisten tilamallien kumulatiivinen maksuvalmiusvaranto siirtymäkauden aikana. Viljanviljely-yritykset. Vaihtoehto II.

Fig. 10. The cumulative balance at the end of each year of alternative types of farms during period of transition. Grain-producing farms. Alternative II. 
Tilanteessa, missä vieraan pääoman osuus on 30-40\% koko pääomasta, tuntuu varsinkin suurimpien tilamallien maksukyky kuitenkin kehittyvän suotuisasti. On huomattava, että mallissa on kaikki käytetyt luvut oletettu täysin varmoiksi.

Yleisesti voidaan todeta, että viljanviljelymalleissa maksuvalmius heikkenee nopeammin vieraan pääoman osuuden kasvaessa kuin maidontuotantomalleissa. Koska laskelmat on tehty keskimääräisiä olosuhteita varten, vaikuttavat esimerkiksi säästä johtuvat tuotostasojen vaihtelut lähinnä yritysten maksuvalmiuteen. Tällaiset vaihtelut lienevät suurempia viljanviljelyssä kuin maidontuotannossa, mikä edelleen heikentää viljanviljelymallien asemaa. 


\section{Yhteenveto}

Tutkimuksen tarkoituksena on ollut maatalouden rakennerationalisoinnin liiketaloudellisten edellytyksien selvittäminen lähinnä Uudenmaan ruotsinkielisen maanviljelysseuran alueella. Erisuuruisten yritysmallien kannattavuutta on tutkittu vertailevan staattisen analyysin avulla. Mallien ratkaisemiseksi on käytetty erästä Monte Carlo -menetelmän muunnelmaa. Rajoittavana tekijänä on malleissa ollut kolme vaihtoehtoista työpanosta, nimittäin 2500 t, 5000 t ja 7500 t työvuotta kohti. Tämän lisäksi on tutkittu kahta tuotantoteknistä tasoa. Jo kirjoittajan aikaisempien tutkimusten perusteella on voitu todeta, että tutkimusalueen viljelijät varsin yleisesti soveltavat malleissa käytettyä alempaa tuotantotekniikkaa. Ainoastaan muutamat harvat viljelijät käyttävät tällä hetkellä malleissa esitettyä ylempää tuotantotekniikkaa.

Muut malleissa edellytetyt tuotannontekijät ovat vapaasti saatavana normaalia korvausta vastaan. Sekä tuotteiden että tarvikkeiden hinnat on sovitettu tutkimusalueella syksyllä 1973 vallinneeseen hintatasoon.

Pellon vuokraksi on malleissa oletettu $300 \mathrm{mk}$ hehtaarilta.

Malliratkaisut osoittivat, että erikoistunut maidontuotanto on kannattavin tuotantosuunta. Erikoistuminen on tässä mallissa viety hyvin pitkälle, koska malliyrityksen tarvitsema rehuvilja ostetaan melkein kokonaan ja ainoastaan nurmirehu tuotetaan omalla tilalla. Erikoistunut maidontuotanto antaa selvästi paremman korvauksen työlle kuin erikoistunut viljantuotanto. Tämä pätee molemmilla teknisillä tasoilla ja kaikenkokoisissa yrityksissä.

Työansio paranee malliratkaisujen mukaan siirryttäessä pienemmästä yrityksestä suurempaan. Paraneminen on kuitenkin ratkaisevasti suurempi siirryttäessä pienimmästä yrityskoosta keskisuureen kuin siirryttäessä keskisuuresta suurimpaan yrityskokoon. Pienin yrityskoko molemmilla teknisillä tasoilla antaa viljanviljelytiloilla negatiivisen työansion. Työansio paranee myös merkittävästi siirryttäessä korkeammalle tuotantotekniselle tasolle.

Pääomantarve on kaikissa mallivaihtoehdoissa hyvin suuri ja se kasvaa myös siirryttäessä alemmalta tuotantotekniseltä tasolta korkeammalle. Merkittävä rakennerationalisointi vaatii siis suuria investointeja. Voidaankin epäillä, löytyykö rahamarkkinoilta tarpeeksi varoja, kun otetaan huomioon kyseisten investointikohteiden suhteellisen heikko kannattavuus. Merkittävät rationalisointimuutokset vaativat yrityksen johtajalta paljon myös maataloudessa, missä yrittäjä johtamistyön lisäksi useimmiten joutuu tekemään pääosan myös ruumiillisesta työstä. Tarvittavan yrittäjäkapasiteetin löytäminen voi näin ollen muodostua vaikeaksi. Tilamalleissa edellytetyt rakenteelliset 
muutokset ovat varsin laajoja. Tulosten mukaan voidaan epäillä, tapahtuuko näin suuria muutoksia käytännössä kovinkaan usein yksittäisillä maatiloilla.

Tutkimuksessa käytetty vertaileva staattinen tarkastelutapa edellyttää, että laajuusasteelta toiselle siirtymisen välillä vallitsee staattisia kausia, jolloin kannattavuus mitataan. Koska siirtyminen vie aikaa mm. sen takia, ettei useinkaan voida välittömästi ottaa käyttöön investoinneilla luotua tuotannon lisäkapasiteettia, tulee yrityksen maksuvalmiuden ylläpitäminen sitä tärkeämmäksi, mitä suuremmaksi lainapääoman osuus koko pääomapanoksesta kasvaa.

Malliyritysten rahavirtoja on tutkimuksessa seurattu simuloimalla viiden vuoden pituisen jakson ajan. Tuloksista voidaan todeta, että siirtyminen korkeimmalle tuotantotekniselle tasolle rasittaa maksuvalmiutta suhteellisesti enemmän kuin siirtyminen keskikorkealle taso'le. Yleisesti ottaen ylimenokauden vaikeudet vaarantavat suhteellisen helposti malliyritysten maksuvalmiutta.

Erikostuneen maidontuotannon mallit tuntuvat sietävän jonkin verran suurempaa lainapääoman osuutta kuin erikoistuneen viljanviljelyn mallit. Maksuvalmiusvaikeudet muodostuvat yleensä kriittisiksi viimeistään, kun lainapääoman osuus malleissa on noin $\mathbf{5 0} \%$ koko pääomasta. Laskelmat on suoritettu keskivuosilaskelmina edellyttäen täydellistä varmuutta. Riskitekijät vaikuttavat näin ollen ensisijaisesti malliyritysten maksuvalmiuteen.

Päättäessäni tämän tutkimuksen on mieluisa velvollisuuteni esittää kiitokseni niille henkilöille ja laitoksille, jotka ovat auttaneet minua työn eri vaiheissa.

Esimiehelleni, professori Nils Westermarck'lle, joka jatkuvasti on tukenut ja kannustanut minua, olen syvästi kiitollinen.

Esitän kunnioittavat kiitokseni tutkimuksen valvojakunnalle, johon kuuluivat agr. GunNar Wickström (puh.joht.), agr. Ralf Karell, prof. MartTi SIPILÄ ja yliarkkit. EERo VäÄNÄNEN. Yhteistyö valvojakunnassa sujui mielestäni esimerkillisellä tavalla ja sain monta rakentavaa ehdotusta.

Prof. E. H. OKSANEN on antanut arvokasta apua tuotantoteknillisten tasojen suunnittelun yhteydessä.

Tutkimukseeni olen saanut apurahaa Maatilatalouden kehittämisrahastolta sekä Kyösti Haatajan rahastolta, joille esitän parhaat kiitokseni. Niin ikään kohdistan kiitokseni Suomen Maataloustieteelliselle Seuralle, joka on ottanut tutkimuksen julkaisusarjaansa.

Helsingissä, joulukuussa 1974

Karl Johan Weckman 


\section{KIRJALLISUUSLUETIELO}

AвEL, W. 1951. Agrarpolitik. Grundriss der Sozialwissenschatt. Band 11. 220 p. Göttingen. BoEHLJE, M. \& White, K. 1969. An analysis of the impact of selected factors on the process of farm firm growth. Purdue univ., research bulletin 854. 23 p. Lafayette.

Boulding, K. 1950. A Reconstruction ef Economics. 311 p. New York.

BRINGBorn, B. \& Hovmark, B. 1971. Lantbruket i Mälar-Hjälmar regionen. En företagsekonomisk studie. Kungl. Lantbruksstyrelsen. Stencil. 266 p. Solna.

CARLsson, M. 1970. Beskrivning av nágra experiment med en Munte Carlo metod för företagsekonomisk planering. Meddelanden från institutionen för ekonomi och statistik. 62 p. Uppsala.

- - Hovmark, B. \& Linugren, I. 1959. A Monte Carlo-method for the study of farm plannin $;$ problems. Review of marketing and agricultur economics. 37,2: 79102. Uppsala.

Christensen, J. 1970. Anvendelse of linear programming og Monte Carlo-metoden ved landbrukets driftsplanleagning. 192 p. Aarhus.

Dent, J. \& Thompson, S. 1967. The application of Monte Carlo techniques to feed nix problems. The Farm Econonist 11,6: 230-248. Oxford.

Donaloson, G. \& Webster, J. 1967. A simulation approach to the selection and combination of farm enterprises. The Farm Economist 11, 6:219-229. Oxford.

НАкоцА, K. 1974. ATK:n käyttö investointılaskelmissa. TKK moniste. 3: 6-8. Helsinki.

IнамиотіLA, R. 1971. Pääoman merkityksestä tuotannontekijänä Suomen maataloudessa vuosina 1948-1970. Osuuspankkijärjestön taloudellinen katsaus. 2: 11-16.

Kungl. Lantbruksstyrelsen 1973. Lantbruket i Mälar-Hjälmar-regionen. En företagsekonomisk studie. Kungl. Lantbruksstyrelsen Medd. 14. 82 p. Stockholm.

LINDBERG, J. 1970. Lantbruket en kapitaltung näringsgren. Ekonomiska samfundets tidskrift 24,4: $296-318$.

LindGren, I. «CARLsson, M. 1966. Fc̈retagskonomisk planering med Monte Carlo-metod. Erhvervsøkonomisk Fidskrift. 2: 61-89. København.

LOFTSGARD, L. D. \& HeAdy, E. O. 1959. Application of dynamic programming models for optimum farm and home plans. Journal of Farm Economics 41: 51-62.

Marshat.l, A. 1922. Principles of Economics. Eight Edition. 871 p. London.

MонR, H. P. 1971. Ein Beitrag zum Betriebsgrössenproblem in der Landwirtschaft unter Besonderer Berucksichtigung Schleswig-Holsteinischer Grossbetriebe. Diss. 204 p. Kiel.

OLsson, R. 1970. En mode!l för studier av jordbruksföretagets tillväxtproblem. Medd. frăn inst. för ekor. och statist. 126 p. Uppsala.

Penrose, R. 1968. The Growth of the Firm. 272 p. Oxford.

Swansson, E. R. 1955. Integrating crop and livestock activities in farm management activity analysis. Journal of Farm Economics 37: 1249-1258.

ToRvelA, M. 1972. Eri tuotantosuuntaa harjoittavien kirjanpitoviljelmien taloudesta EteläSuomessa vuonna 1970. Maatal. hall. Aikak. 4: 4-11.

- - \& MãKı, S. 1974. Perheviljelmän koko rationaalisessa maataloustuotannossa. Maatal. Tal. tutk.lait. Julk. 30. 79 p.

Tuisku, J. 1973. Peltojen investointitutkimus - mitä se on ja mitä se ei ole. Käytännön Maamies 3: 10-11.

Weскмan, K. J. 1972. Lantbrukets strukturrationalisering i Snappertuna. Lantbruksekon. inst. vid Helsingfors univ. pubi. $88 \mathrm{p}$.

- - - 1972. Lantbrukets framtid i kommunerna Snappertuna och Liljendal. Särtryck ur NSL:s ârsbok 1971. 13 p. Bor żå.

Westermarck, N. \& MattiLA, L. 1969. Maatilasuunnittelun normikirja. $326+11$ p. Hel sinki. 


\section{Summary}

\section{On Micro-Economic precanditions required for the Structural Changes in Agriculture. Studies of Farm growth in South Finland.}

Karl Johan Weckman.

Depariment of Agricultural Economics, University of Helsinki.

The possibilities for structural change has increasingly dominated discussions on the economic viability of agriculture as a means of livelihood. In most cases the measures which irfluence the structure of an farm enterprise call for relatively large investments. The anticipated profits on these investments and the influence of these investments on the profitability of the enterprise greatly influence many future decisions concerning investments.

The main purpose of this investigation is to throw some light on these problems where they concern the area of the Swedish-speaking Agricultural Society in Uusimaa. By using farms models an estimate can be made of the profitability of different lines of production, of difforent levels of production and of different sized enterprises. In this way we can determine which enterprises are most likely to be economically successful. Calculations concerning the investment and paying readynes and solvency of these enterprises can then also be made.

The so called Monte Carlo (M-C) system has been chosen as the method of calculation. This method is believed to provide certain advantages ove1 several other methods. Moreover this belief seems to be justified by the fact that there is no need for a predetermined relation between the input and output of the average farn. Furthermore, the establishment of several alternative results having an equal value can be of use in decision-making.

Three alternative work inputs of $2500 \mathrm{~h}, 5000 \mathrm{~h}$ and $7500 \mathrm{~h}$ per work year constitute a limiting factor for the average farm. Two levels of production have been examined. Previous investigations have shown that the farmers in the area under investigation quite commonly apply the less advanced production techniques used on a typical farm. Only a small number of farmers currestly use the more advanced production techniques. Other requirements for production have been met at normal prices in the models. The prices of both the products and the needs of production have been adjusted for the prevailing prices of the final quarter of 1973 .

The rent paid for the arable land by the farm models has been Fmk 300 per hectare. The results show that specialized milk production was the most profitable line of production. Specialization was highly developed with nearly all fodder being bought and only the rongh fodder being grown on the farm itself. Examination of farms specializing in grain cultivation shows that a milk producing farm gives better economic results than one specialized in producing grain. This result is true for different levels of technical development as well as for all sizes of enterprises.

According to the solutions, the economic result gradually improves as we move towards larger enterprises. However, the relative gap is considerably wider when moving from a small to a medium size farm than when moving from a medium size farm to the largest 
farm. The smallest grain producing enterprises show a negative yield at each technical level. The yield improves noticeably when more rationalized production methods are used.

The need for capital is great on each of the types of farms models examined. This need grows in proportion to the level of rationalization in the production methods. Structural rationalization thus demands considerable investments. It is doubful whether funds can be found on the open market for enterprises which are not very profitable. Any notable structural rationalization demands a great deal from the manager of the enterprise, and this is true even in agriculture where the entrepreneur performs the greater part of the required physical work in addition to this managerial work. Concequently it is often difficult to find pcople with sufficient managerial ability.

In this investigation the method used of comparing static examples of farms presupposes that oiter the transition from one size to another, farms undergo a static period during which their profitability can be measured. Since this transition often takes time, on account of the fact that often it is not possible to make immediate use of the increased production capacity brought about by the new investments, the maintenance of paying readynes for the enterprise becomes an increasingly important factor. This problem of readynes to pay becomes more important as the relative size of the loan increases.

This investigation has been examining the simulated cash-flow on farm models during the transition from one size to another. The results indicate that the transition to the highest technical level constitutes a more serious burden on the farm's solvency and readynes to pay than when a move is made to the medium technical level.

Those enterprises which specialize in milk production seem to be able to handle a somewhat higher proportion of loaned capital than the enterprises specializing in grain production. On the whole the obstacles to paying readynes reach a critical point when the loan constitutes more than $50 \%$ of the total capital invested. These calculations have beer made on the basis of an average year and full certainty. Therefore the risk factors concern mainly the paying readynes of the farms. 